AperTO - Archivio Istituzionale Open Access dell'Università di Torino

\title{
Photoelectrochemical Performance of the Ag(III)-Based Oxygen-Evolving Catalyst
}

\section{This is the author's manuscript}

Original Citation:

Availability:

This version is available http://hdl.handle.net/2318/1657507

since 2018-01-15T11:40:08Z

Published version:

DOI:10.1021/acsami.7b05901

Terms of use:

Open Access

Anyone can freely access the full text of works made available as "Open Access". Works made available under a Creative Commons license can be used according to the terms and conditions of said license. Use of all other works requires consent of the right holder (author or publisher) if not exempted from copyright protection by the applicable law. 


\section{Photoelectrochemical Performance of the $\mathrm{Ag}(\mathrm{III})$ -}

\section{based Oxygen Evolving Catalyst}

Fabrizio Sordello, Manuel Ghibaudo, Claudio Minero*

Dipartimento di Chimica, Università degli Studi di Torino - via Pietro Giuria 5 -10125 Torino, Italy

KEYWORDS: water splitting, artificial photosynthesis, oxygen evolving catalyst, silver oxide, hematite, $\mathrm{TiO}_{2}$.

\section{ABSTRACT}

We report the electrosynthesis of a water oxidation catalyst based on Ag oxides (AgCat). The deposited AgCat is composed of mixed valence crystalline Ag oxides with the presence of particle aggregates whose size is around $1 \mu \mathrm{m}$. This catalyst, coupled with $\mathrm{TiO}_{2}$ and hematite, and under photo-electrochemical conditions, substantially increases photocurrents in a wide range of applied potentials compared with bare and Co-Pi-modified photocatalysts. AgCat can sustain current densities comparable with other water oxidation catalysts. Dark bulk electrolysis demonstrated that $\mathrm{AgCat}$ is stable and can sustain high turnover number in operative conditions. Oxygen evolution from water occurs in mild conditions: $\mathrm{pH}=2-13$, at room temperature and pressure, and moderate overpotentials $(600 \mathrm{mV})$ compatible with the coupling with semiconducting oxides as sensitizers. Using hematite in sustained electrolysis $\mathrm{O}_{2}$ production is significant, both in the dark and under irradiation, after an initial slow induction time in which modification of surface species occurs. 


\section{INTRODUCTION}

The water splitting reaction is of fundamental importance in the storage of solar energy and in its conversion to fuels. The reaction is thermodynamically disfavored, because of its high reduction potential, and kinetically hindered owing to the two multi-electron half reactions involved. Bare common photocatalysts $\left(\mathrm{ZnO}, \mathrm{SnO}_{2}, \mathrm{WO}_{3}, \mathrm{Fe}_{2} \mathrm{O}_{3}\right.$ and $\left.\mathrm{TiO}_{2}\right)$, which present strongly oxidizing valence band potentials $(\mathrm{E}>2 \mathrm{~V} \text { vs } \mathrm{Ag} / \mathrm{AgCl} \text { at } \mathrm{pH} 1)^{1}$, are usually quite inefficient, as photoholes are accumulated at the solid/water interface. This favors electron-hole recombination and promotes the side production of species which are kinetically competitive with molecular oxygen. Advantageous photocurrents are usually obtained through large applied potentials only. For efficient water oxidation an oxygen evolving catalyst is needed to favor water oxidation itself over side reactions and recombination of photo-generated species. Homogeneous ${ }^{2}$ and heterogeneous ${ }^{3}$ photocatalysts $^{4-5}$ and electrocatalysts ${ }^{6-9}$ have been proposed, although they usually have high overpotential.

Cobalt-based oxides have shown promising potential for photocatalytic water oxidation. Among these, cobalt phosphate (Co-Pi) presents several advantages compared with precious metal oxides $\left(\mathrm{RuO}_{2}, \mathrm{IrO}_{\mathrm{x}}\right)$ or spinel and perovskite metal oxides $(\mathrm{Mn})$, which require extreme $\mathrm{pH}$ conditions. ${ }^{10}$ Co-Pi as a co-catalyst has been reported ${ }^{11-12}$ to enhance the efficiency of water photo-oxidation when it is coupled with $\mathrm{WO}_{3},{ }^{13} \mathrm{ZnO},{ }^{12} \mathrm{Si}^{14}, \alpha-\mathrm{Fe}_{2} \mathrm{O}_{3} .{ }^{13,15-19}$ When coupled with $\mathrm{BiVO}_{4}{ }^{20-23} \mathrm{Co}-\mathrm{Pi}$ shows larger $\mathrm{O}_{2}$ production and photocurrent density as compared with $\mathrm{CoO}_{\mathrm{x}}, \mathrm{IrO}_{\mathrm{x}}, \mathrm{MnO}_{\mathrm{x}}$ and $\mathrm{RuO}_{2}{ }^{22}$. The mechanism of Co-Pi on $\alpha-\mathrm{Fe}_{2} \mathrm{O}_{3}{ }^{24}$ and on $\mathrm{WO}_{3}{ }^{25}$ shows that the performance of the semiconductor-cocatalyst coupled system critically depends on the properties of both.

Reports on the coupling of Co-Pi to $\mathrm{TiO}_{2}$ are few, compared with the vast literature dealing with the use of this semiconductor for remediation. ${ }^{26}$ The deposition of $8 \mu \mathrm{m}$ thick Co-Pi on $\mathrm{TiO}_{2}$ prepared from titanium(IV) isopropoxide ${ }^{27}$ showed that Co-Pi produces $\mathrm{O}_{2}$ at a rate of about $4 \mu \mathrm{mol} \mathrm{h}^{-1}$ in the 
dark under controlled potential electrolysis. The deposition was able to give interesting photocurrents and $\mathrm{O}_{2}$ production rates up to $7 \mu \mathrm{mol} \mathrm{h}{ }^{-1}$, even though at a rather high light intensity $\left(2000 \mathrm{~W} \mathrm{~m}^{-2}\right)$. Co-Pi/Pt deposition on a $\mathrm{TiO}_{2}$ plate-like structure, with a width of several micrometers, showed 300 times higher photoactivity than standard $\mathrm{TiO}_{2}$ photocatalysts. ${ }^{28}$ The combination of $\mathrm{Co}-\mathrm{Pi} / \mathrm{Pt}$ deposition and anisotropic electron flow due to the plate structure of $\mathrm{TiO}_{2}$ significantly reduced the electron/hole recombination. ${ }^{24} \mathrm{I}-\mathrm{V}$ curves under dark and illumination on either Co-Pi deposited on homemade $\mathrm{TiO}_{2}{ }^{29}$ or on nanowire arrays ${ }^{30}$ confirmed that a photocurrent larger than the dark current is present when the starting applied potential is quite negative $(-0.4 \mathrm{~V}$ vs $\mathrm{Ag} / \mathrm{AgCl}$ or 0.15 vs RHE, respectively). It also confirmed that, depending on the amount of Co-Pi deposited, there is an inversion of the two currents when Co-Pi is under a proper redox condition for water oxidation. Our results on home prepared anatase thin films also showed that Co-Pi gave neither photocurrents nor oxygen evolution at low irradiation intensity (see infra). In summary, photocurrent measurements showed that under electrochemical conditions Co-Pi is a good water oxidation catalyst, although under illumination it can recombine photoelectrons and holes when coupled with semiconductors. The amount of recombination depends on the specific electronic properties of the photocatalyst, as it was the case for plate-like $\mathrm{TiO}_{2},{ }^{28}$ which has marked intrinsic ability to favor charge separation.

Here we report on the characterization and performance of a silver oxide - based oxygen evolving catalyst (AgCat) formed in situ upon anodic polarization of an inert electrode in acidic aqueous solution of $\mathrm{Ag}^{+}$. Silver and silver oxides have been deeply investigated for application in various electrochemical processes, for example as the catalytic cathode material in fuel cells ${ }^{31}$ or as a component of fast ion conducting glasses that can serve as a solid state electrolyte. ${ }^{32}$ Different silver oxides $\left(\mathrm{Ag}_{2} \mathrm{O}_{3}, \mathrm{Ag}_{2} \mathrm{O}_{2} \text { and } \mathrm{Ag}_{3} \mathrm{O}_{4}\right)^{33}$ are suitable for water oxidation. $\mathrm{Ag}_{2} \mathrm{O}_{3}$ has had considerably weak attention in literature than $\mathrm{Ag}_{2} \mathrm{O}$, most likely due to its poor stability. $\mathrm{Ag}_{2} \mathrm{O}_{3}$ possesses an orthorhombic structure with slightly distorted $\mathrm{AgO}_{4}$ subunits, and $\mathrm{d}^{8} \mathrm{Ag}(\mathrm{III})$ ions have an 
approximate square planar co-ordination with four oxygen atoms. ${ }^{33} \mathrm{McMillan}^{34}$ first suggested that $\mathrm{AgO}$ was a mixed valence compound, containing an equal number of $\mathrm{Ag}(\mathrm{I})$ and $\mathrm{Ag}(\mathrm{III})$ cations, so the oxide is more accurately described as $\mathrm{Ag}^{\mathrm{I}} \mathrm{Ag}^{\mathrm{III}} \mathrm{O}_{2}\left(\mathrm{Ag}_{2} \mathrm{O}_{2}\right)$. The oxide structure consists of a distorted face-centered cubic arrangement of metal ions, with $\mathrm{Ag}(\mathrm{I})$ cations linearly co-ordinated with two oxygen anions, and $\mathrm{Ag}(\mathrm{III})$ cations approximately square planar co-ordinated with four oxygen anions. Each oxygen atom is co-ordinated by two $\mathrm{Ag}(\mathrm{III})$ cations and one $\mathrm{Ag}(\mathrm{I})$ cation, and the bonding geometry at oxygen is approximately trigonal pyramidal. ${ }^{35}$ The electronic structure of silver oxides has also been recently calculated ${ }^{36}$ and investigated through XANES spectroscopy. ${ }^{37}$ Continuous films of $\mathrm{Ag}_{2} \mathrm{O}_{2}$ have been already electrodeposited from aqueous acetate salts and characterized. The $\mathrm{Ag}_{2} \mathrm{O}_{2}$ film has a direct optical bandgap of $1.1 \mathrm{eV}$ and is quite conductive, as the four-point resistivity is $12 \pm 1 \Omega \mathrm{cm} .^{38}$

The thermal stability of $\mathrm{Ag}_{2} \mathrm{O}_{2}$ is poor as it easily decomposes at $\mathrm{T}>373 \mathrm{~K}$ to form $\operatorname{Ag}_{2} \mathrm{O}_{(\mathrm{s})}$ and $\mathrm{O}_{2(\mathrm{~g}) \cdot}{ }^{35}$ Also $\mathrm{Ag}_{2} \mathrm{O}_{3}$ and $\mathrm{Ag}_{3} \mathrm{O}_{4}$ readily decompose to give $\mathrm{Ag}_{2} \mathrm{O}_{2}$ at room temperature in 1 hour. ${ }^{33}$ Because silver is not known to take the $\mathrm{Ag}(\mathrm{IV})$ valence, ${ }^{35}$ this thermal instability suggested to us that under electrochemical bias $\mathrm{Ag}_{2} \mathrm{O}_{3}$ and $\mathrm{Ag}_{2} \mathrm{O}_{2}$ could easily evolve $\mathrm{O}_{2(\mathrm{~g})}$ and the possibly formed $\mathrm{Ag}(\mathrm{I})$ could be at once re-oxidized to $\mathrm{Ag}_{2} \mathrm{O}_{2}$ under electrochemical or photoelectrochemical conditions.

Ag-based catalysts, such as Ag carbonate ${ }^{39}, \mathrm{Ag}$ tetraborate, ${ }^{40}$ or $\mathrm{Ag}$ oxides $^{41}$ have been reported, bearing witness to the potential of Ag-based co-catalysts to perform water oxidation. Such materials, however, have not been previously coupled with semiconductors to perform water photosplitting. Their stability, too, at a different $\mathrm{pH}$ and electrolyte composition has not been evaluated.

In this work AgCat was deposited on $\mathrm{TiO}_{2}$ and on hematite, and its performance measured through photoelectrochemical techniques and gaseous $\mathrm{O}_{2}$ quantitation. The results have been compared with 
those obtained through Co-Pi deposited on the same substrates as reference. The electrosynthesis conditions have been optimized, and the $\mathrm{i}-\mathrm{V}$ characteristics recorded in a wide range of $\mathrm{pH}$ and solution compositions.

\section{EXPERIMENTAL SECTION}

\section{Materials}

Transparent conductive supports (Corning® EXG alkaline earth boro-aluminosilicate glass, 25 x 25 x $1.1 \mathrm{~mm}$, Indium Tin Oxide coated on one surface, $\mathrm{Rs}=9-15 \Omega$, Transmission $>80 \%$, ) were bought from Delta Technologies Ltd (USA).

For the operation and the calibration of the flow controller and $\mathrm{GC}$ apparatus, $\mathrm{Ar}, \mathrm{He}, \mathrm{N}_{2}, \mathrm{O}_{2}$ pure gases (>99.9995\%) were employed (Sapio, Turin), and proper standard mixtures were prepared in canisters by dilution.

\section{Preparation of $\mathrm{TiO}_{2}$ and hematite electrodes}

$\mathrm{TiO}_{2}$ electrodes were made through dip-coating immersing conductive glass slides into a $\mathrm{TiO}_{2}$ suspension composed of 20-30 nm anatase particles dispersed in butan-1-ol. The $\mathrm{TiO}_{2}$ particles were obtained from Ti-isopropoxide partially hydrolyzed with water and nitric acid in the presence of non-ionic surfactants. ${ }^{42}$ After immersion the conductive substrate was withdrawn at $2 \mathrm{~cm} \mathrm{~min}^{-1}$, and, then, the thin homogeneous films obtained were calcined at $450^{\circ} \mathrm{C}$ for $8 \mathrm{hrs}$.

Hematite thin films were electrodeposited (ED) on conductive glass starting from a solution containing $\mathrm{FeSO}_{4} 0.1 \mathrm{M}$ and $\mathrm{KNO}_{3} 0.1 \mathrm{M}$ and imposing $0.8 \mathrm{~V}$ vs $\mathrm{Ag} / \mathrm{AgCl}$ for $3000 \mathrm{~s}$ at the working electrode (WE) kept at $30^{\circ} \mathrm{C}$; in these conditions the current density recorded was $0.75 \mu \mathrm{A}$ $\mathrm{cm}^{-2}$. To improve hematite film quality (and increase the charge carrier lifetime), hematite was deposited also through Pulse Reverse ElectroDeposition (PRED): at a constant potential of 0 V vs $\mathrm{Ag} / \mathrm{AgCl}$ a pulse of the duration of $9.0 \mathrm{~ms}$ at $6 \mathrm{~V}$ vs $\mathrm{Ag} / \mathrm{AgCl}$ was superimposed every $10.0 \mathrm{~ms}$. 


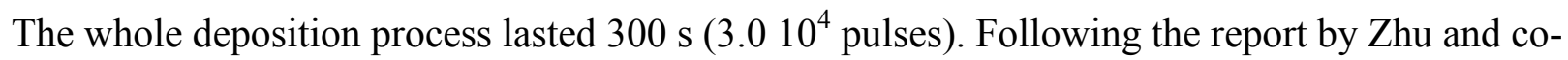
workers ${ }^{43}$ we used a solution of $\mathrm{FeSO}_{4} 0.4 \mathrm{M}$, ascorbic acid $10 \mathrm{mM}$, sulfamic acid $5 \mathrm{mM}$, and boric acid $0.3 \mathrm{M}$.

\section{Co-Pi and AgCat synthesis}

In accordance with previous reports, ${ }^{3} \mathrm{Co}-\mathrm{Pi}$ catalyst used as reference was synthesized on ITO at $1.1 \mathrm{~V}$ vs $\mathrm{Ag} / \mathrm{AgCl}$ for $1200 \mathrm{~s}$ starting from $\mathrm{Co}\left(\mathrm{NO}_{3}\right)_{2} 0.5 \mathrm{mM}$ in a phosphate buffer $0.1 \mathrm{M}$ at $\mathrm{pH} 7$. The coupling of Co-Pi to n-type semiconductors such as $\mathrm{TiO}_{2}$ and hematite was done through photoelectrochemical deposition at a potential which was less positive than the one used for ITO, as suggested for $\mathrm{ZnO}^{12}$ and $\mathrm{TiO}_{2},{ }^{30}$ using an applied potential of $0.7 \mathrm{~V}$ vs $\mathrm{Ag} / \mathrm{AgCl}$ for $1200 \mathrm{~s}$ on a solution of $\mathrm{Co}\left(\mathrm{NO}_{3}\right)_{2} 0.5 \mathrm{mM}$ in a phosphate buffer $0.1 \mathrm{M}$ at $\mathrm{pH} 7$.

AgCat was synthesized on ITO conductive glass by means of electrodeposition (ED), exploring different potentials (between $1.7 \mathrm{~V}$ and $2.2 \mathrm{~V}$ vs $\mathrm{Ag} / \mathrm{AgCl}$ ), deposition time (between $600 \mathrm{~s}$ and $1500 \mathrm{~s}$ ), $\mathrm{Na}_{2} \mathrm{SO}_{4}$ concentration (between 0 and $10 \mathrm{mM}$ ), and $\mathrm{pH}$ (between 2 and 5). The $\mathrm{AgNO}_{3}$ concentration was kept fixed at $1 \mathrm{mM}$. The sulfate buffer was occasionally used to fix the $\mathrm{pH}$ and, depending on its different oxidation states, to regulate Ag solubility, so as to avoid the dissolution of the electrosynthesized catalyst, and $\mathrm{Ag}(\mathrm{I})$ precipitation (for $\mathrm{Ag}_{2} \mathrm{SO}_{4} \mathrm{k}_{\mathrm{sp}}=1.210^{-5}$, Figure $\mathrm{S} 1$ in Supporting Information).

The coupling of AgCat to n-type semiconductors, such as $\mathrm{TiO}_{2}$ and hematite, was done through photoelectrochemical deposition (AgCat(PED)) at a potential which was less positive than the one used for ITO: $1.3 \mathrm{~V}$ vs $\mathrm{Ag} / \mathrm{AgCl}$ for $3800 \mathrm{~s}$ in $\mathrm{AgNO}_{3} 1 \mathrm{mM}$ and $\mathrm{KNO}_{3} 0.1 \mathrm{M}$. Here we report the results for the photoelectrochemical deposition method only, because the electrodeposition gives worse results. The photoelectrochemical deposition is advantageous because the catalyst is deposited on surface sites where holes are more efficiently trapped and, conversely, electrons are not. This would improve the charge separation in the hybrid catalyst. ${ }^{12}$ We also developed a PRED 
method (AgCat(PRED)). On the just synthesized AgCat(PED) in $1 \mathrm{mM} \mathrm{AgNO}$ and $0.1 \mathrm{M} \mathrm{KNO}_{3}$ solution, a constant potential of $0 \mathrm{~V}$ vs $\mathrm{Ag} / \mathrm{AgCl}$ was applied, over which every $10.0 \mathrm{~ms}$ a pulse of the duration of $9.0 \mathrm{~ms}$ at $6 \mathrm{~V}$ vs $\mathrm{Ag} / \mathrm{AgCl}$ was superimposed. The whole process lasted for $300 \mathrm{~s}$ (3.0 $10^{4}$ pulses).

After the synthesis the catalyst performance was tested for the electrocatalytic water oxidation through linear sweep voltammetry (LSV). $\mathrm{KNO}_{3}$ solution $0.100 \mathrm{M}$ was brought at $\mathrm{pH} 2$ with $\mathrm{HNO}_{3}$, and $\mathrm{pH} 7,8.8$ and 11 were set with the addition of $\mathrm{H}_{3} \mathrm{PO}_{4}$ to sodium phosphate $0.100 \mathrm{M}$. All the measurements were performed in the absence of dissolved silver in the electrolyte. The ITO substrate covered with AgCat was polarized between $0.8 \mathrm{~V}$ and $2 \mathrm{~V}$ vs $\mathrm{Ag} / \mathrm{AgCl}$ at a $100 \mathrm{mV} \mathrm{s}^{-1}$ scan rate to detect the anodic current resulting from water oxidation. To demonstrate the catalytic behavior and to test the stability of AgCat, bulk electrolysis was carried out for long time in a sulfate buffer solution $0.010 \mathrm{M}$ at $\mathrm{pH} 2$, imposing a potential of $1.85 \mathrm{~V}$ vs $\mathrm{Ag} / \mathrm{AgCl}$.

\section{Instrumentation}

The electrochemical experiments were carried out through a standard photoelectrochemical set-up and a computer-controlled potentiostat (PGSTAT12, Autolab). The electrochemical cell was a conventional three-electrode cell. The counter and reference electrodes were a Pt sheet and the $\mathrm{Ag} / \mathrm{AgCl} / \mathrm{KCl}$ (3 M) electrode, respectively. The electrolytic solution was purged through nitrogen gas.

To investigate the mechanism of electrocatalytic water oxidation we performed electrochemical impedance spectroscopy (EIS) on AgCat thin films in the potential range 1.6-1.9 V vs $\mathrm{Ag} / \mathrm{AgCl}$ with frequency between $10 \mathrm{kHz}$ and $0.1 \mathrm{mHz}$. We used a $\mathrm{R}_{\mathrm{s}}\left(\mathrm{R}_{\mathrm{f}} \mathrm{Q}\right)$ equivalent circuit to fit the data. The $R_{f}$ values were used to get the Tafel plot (- $\log \left(R_{f}\right)$ vs $\left.E\right)$, from which information was gained about the reaction mechanism. The electrolytes were $\mathrm{K}_{2} \mathrm{SO}_{4} 10 \mathrm{mM}$ at $\mathrm{pH} 2$ and $\mathrm{pH} 5$, and $\mathrm{K}_{2} \mathrm{SO}_{4}$ $100 \mathrm{mM}$ at $\mathrm{pH}$ 2. In all cases the ionic strength was buffered with $\mathrm{KNO}_{3}$ to $1.5 \mathrm{M}$. A $150 \mathrm{~W}$ Xe $\operatorname{arc}$ 
lamp was used as a light source, with a LOT Oriel power supply and lamp housing. To reject the IR part of the lamp radiation, a glass cell filled with distilled water as absorption liquid was placed on the light beam. The beam was collimated with lenses with the photoanode cell. The incident light intensity at the location of the working electrode was $2.8 \mathrm{~W} \mathrm{~m}^{-2}$, measured through a radiant power/energy meter in the $290-400 \mathrm{~nm}$ spectral range and $42 \mathrm{~W} \mathrm{~m}^{-2}$ in the $290-800 \mathrm{~nm}$ spectral range. The light intensity employed is rather low compared with reported values. ${ }^{27}$ The low intensity is enough to trigger photoelectrocatalysis and allows better discernment between electrocatalytic and photoelectrocatalytic processes. Larger light intensity would simulate the functioning of the materials under natural solar light, which is not yet the goal of the present work. Conversely, more intense irradiation favors recombination on the semiconductor, as it is well established in photocatalysis, ${ }^{26}$ and possibly obscure the possible role of the co-catalyst as a recombination site.

The measurement of molecular oxygen was carried out in a continuously stirred tank reactor (CSTR) under flow. This configuration: a) reduces the continuous increase of $\mathrm{O}_{2}$ inside the cell from unavoidable leaks that increase the errors in the evaluation of net $\mathrm{O}_{2}$ produced; ${ }^{25} \mathrm{~b}$ ) under steady state condition it avoids the correction for the $\mathrm{O}_{2}$ partition between the liquid and gas phase controlled by Henry law. A Smart Trak 100 (Sierra) flow controller C100L was used to maintain a constant $\mathrm{N}_{2}$ flow of $20.0 \mathrm{~mL} \mathrm{~min}^{-1}$ through the electrochemical cell. The electrochemical cell used for $\mathrm{O}_{2}$ measurement was a custom-built airtight two-compartment cell divided by a frit, in which opposite to the frit there was a flat quartz window. Inside the working electrode compartment the electrolyte volume is $36 \mathrm{~mL}$, with a head space of $20 \mathrm{~mL}$. The gas flow leaving the cell was analyzed every 3 min through an Agilent 490 Micro GC gas chromatograph equipped with a Molsieve $5 \AA$ kept at $90^{\circ} \mathrm{C}$ and $200 \mathrm{kPa}$ and a thermal conductivity detector for the determination of $\mathrm{O}_{2}$. The carrier gas was Ar. We preferred GC analysis as carried out by others ${ }^{22,27,44}$ instead of using a fluorescence-based oxygen sensor ${ }^{24-25}$ which has the advantage of sensitivity, but can suffer 
from possible interference by quenching from other oxidant species produced, on which no data are available. The minimum detectable $\mathrm{O}_{2}$ concentration with GC measurements is $2.5 \mu \mathrm{L} \mathrm{L}^{-1}$ (50 $\left.\mathrm{nmol} / \mathrm{L}^{-1}\right)$, corresponding to a minimum rate of $\mathrm{O}_{2}$ production of $0.05 \mu \mathrm{L} \mathrm{min}^{-1}\left(0.12 \mu \mathrm{mol} \mathrm{h}^{-1}\right)$ under $\mathrm{N}_{2}$ flow of $20.0 \mathrm{~mL} \mathrm{~min}^{-1}$. The faradaic efficiency was calculated as the ratio of $(4 \times$ moles $\mathrm{O}_{2}$ produced $) /($ moles of electrons $)=\left(4 \times \mathrm{O}_{2}\right.$ production rate $\left.\left[\mathrm{mol} \mathrm{s}^{-1}\right]\right) /\left(\mathrm{A}_{\mathrm{el}} / \mathrm{F} \times\right.$ current density $)$, where $\mathrm{A}_{\mathrm{el}}$ is the geometric area of the electrode, $\mathrm{F}$ the Faraday constant and the current density is the current measured at a given applied potential divided by $\mathrm{A}_{\mathrm{el}}$.

The crystal composition of the synthesized films was obtained using a Philips PW 3830 diffractometer equipped with a PW 3020 goniometer, a PW 3710 MPD control X-ray diffraction system and a PW $1140 \mathrm{Cu} \mathrm{K \alpha}$ radiation source generator operated at $40 \mathrm{kV}$ and $30 \mathrm{~mA}$. The morphology of the films was determined through a Phenom-World Phenom Pro Desktop SEM.

For detection of $\mathrm{FeO}_{4}{ }^{2-}$ (at $505 \mathrm{~nm}$, molar absorption $1070 \pm 30 \mathrm{M}^{-1} \mathrm{~cm}^{-1}$ ) ${ }^{45} \mathrm{UV}-\mathrm{V}$ is spectra were acquired using a Cary 100 UV-Vis spectrophotometer, 9.00 (Varian) version. Spectra were registered in the $200-900 \mathrm{~nm}$ range at a scan rate of $300 \mathrm{~nm} \mathrm{~min}^{-1}$ with a step size of $0.5 \mathrm{~nm}$; the UV source changeover was set up at $350 \mathrm{~nm}$. The minimum appreciable absorbance in the experimental conditions adopted is $1 \cdot 10^{-3}$. This implies that the lowest detectable $\mathrm{FeO}_{4}{ }^{2-}$ concentration is $1 \cdot 10^{-6}$ M.

\section{RESULTS AND DISCUSSION}

\section{Characterization}

AgCat, $\mathrm{Co}-\mathrm{Pi}, \mathrm{TiO}_{2}$ and hematite were deposited on ITO because ITO is stable at oxidizing potentials, conductive and transparent, allowing irradiation on both sides of the deposited film. For this reason transparent conductive glass supports are commonly used, as they are fundamental components of photoelectrochemical cells. ${ }^{3-4,9,14,20,23-24,46}$ 
The morphology of AgCat electrochemically deposited on ITO (ITO-AgCat(ED)) revealed by means of SEM (Figure 1) is dominated by $0.5-1 \mu \mathrm{m}$ octahedral particles, in accordance with what de Groot and co-workers very recently observed. ${ }^{41}$ Each particle is mostly separated from the others, and the bare substrate is partly uncovered. The condition of the synthesis $(\mathrm{pH}, \mathrm{Ag}(\mathrm{I})$ concentration, applied potential and deposition time) strongly influences the surface morphology of AgCat without substantially changing the i-V performance. Since AgCat is in the form of particles, once these are deposited on the surface of wide band gap semiconductors, it will form an adaptive junction, in which the electrolyte permeates around and through the catalyst reaching the semiconductor, and screening the catalyst charge with mobile ions. Therefore there will be no electrostatic potential drop within the catalyst, leading to larger photovoltage compared to dense catalysts. ${ }^{46}$ In an adaptive junction the current response should be independent of the catalyst employed, as long as the catalyst itself does not act as a recombination center. ${ }^{46}$ According to previous reports ${ }^{3,47-48}$ the electrolyte can penetrate also into a Co-Pi porous structure, allowing the direct comparison of the results obtained with the two different catalysts. This, therefore, will reveal which of the two co-catalysts under study is mainly promoting recombination of the photogenerated charge carriers. 


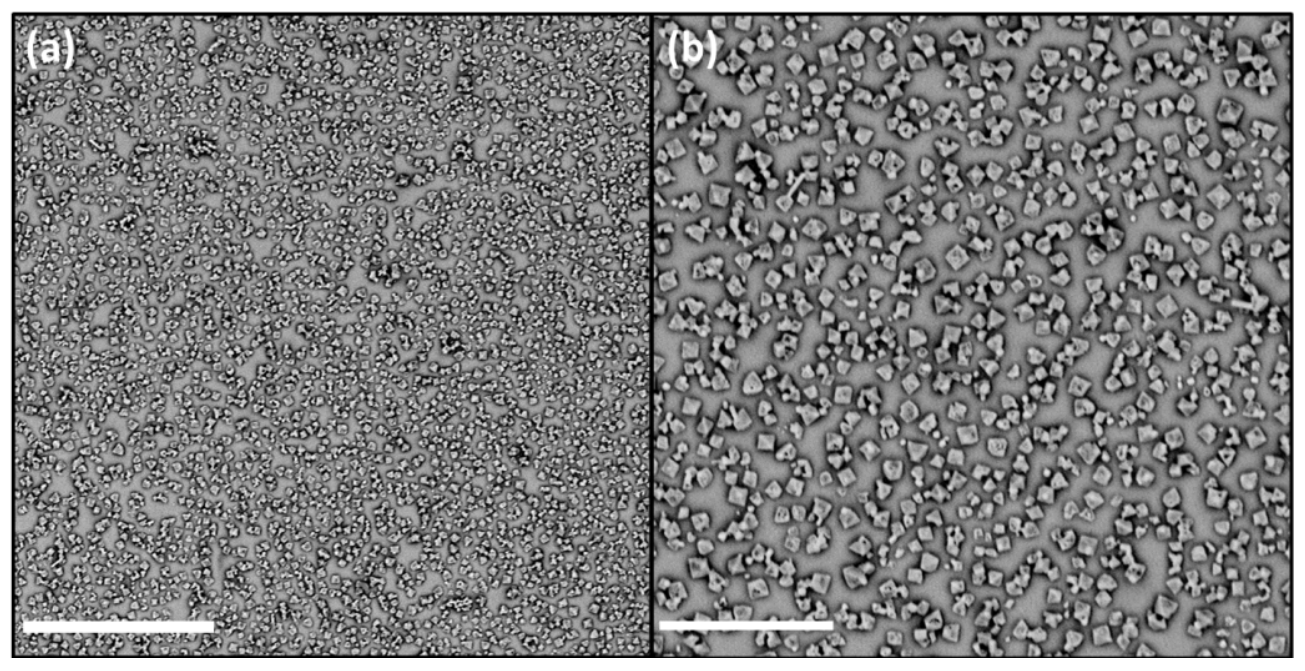

Figure 1. SEM micrographs of the ITO-AgCat(ED) electrochemically deposited from $\mathrm{AgNO}_{3} 1$ $\mathrm{mM}$ at $1.85 \mathrm{~V}$ for $1050 \mathrm{~s}$ at $\mathrm{pH} 7$ in $0.1 \mathrm{M} \mathrm{KNO} 3$ at $4000 \mathrm{x}$ (a) and $9400 \mathrm{x}$ (b) magnifications. Scale bar is $20 \mu \mathrm{m}$ in (a) and $8 \mu \mathrm{m}$ in (b).

X-ray diffractograms (Figure 2b) are only partially informative, as the catalyst features poor stability at room temperature and without applied bias. XRD patterns are also complicated by the presence of the ITO substrate peaks. Figure 2a reports XRD diffractogram of ITO-AgCat(ED) synthetized at $\mathrm{pH} 2$ and potential $1.85 \mathrm{vs} \mathrm{Ag} / \mathrm{AgCl}$ in the presence of sodium sulfate $10 \mathrm{mM}$, that partially stabilizes the catalyst. Nine narrow peaks (with $2 \theta=21.4,27.9,31.3,32.3,34.0,38.2,44.4$, 46.5, 64.6) can be assigned to AgCat, showing, together with the regular octahedral particles of Figure 1, that it is crystalline, even if its deposition is carried out at room temperature, and no thermal treatment is performed to increase crystallinity. The peak positions and relative intensities are not compatible with only one crystalline phase, but at least with three. No peaks can be assigned to $\mathrm{Ag}_{2} \mathrm{O}$, whereas the peaks at $2 \theta=32.3$ and 38.2 are due to $\mathrm{Ag}_{2} \mathrm{O}_{2}$ phase. ${ }^{35}$ Even though $\mathrm{Ag}_{2} \mathrm{O}_{3}$ and $\mathrm{Ag}_{3} \mathrm{O}_{4}$ could be formed at the potentials used during electrosynthesis (Figure $\mathrm{S} 1$ in Supporting Information), their presence cannot be revealed, because they readily decompose to give $\mathrm{Ag}_{2} \mathrm{O}_{2}$ at room temperature. ${ }^{33}$ 
Since the XRD analysis cannot be carried out under the catalyst working conditions, the characteristic peaks of metallic $\mathrm{Ag}(2 \theta=38.2,44.4,64.6)$ can be observed, a phenomenon also recently described by de Groot and co-workers. ${ }^{41}$ The peaks at $2 \theta=21.4,27.9,31.3,34.0$ and 46.5 can be assigned to $\mathrm{Ag}_{2} \mathrm{SO}_{4}$, which is formed when the synthesis is carried out in the presence of sulfate.

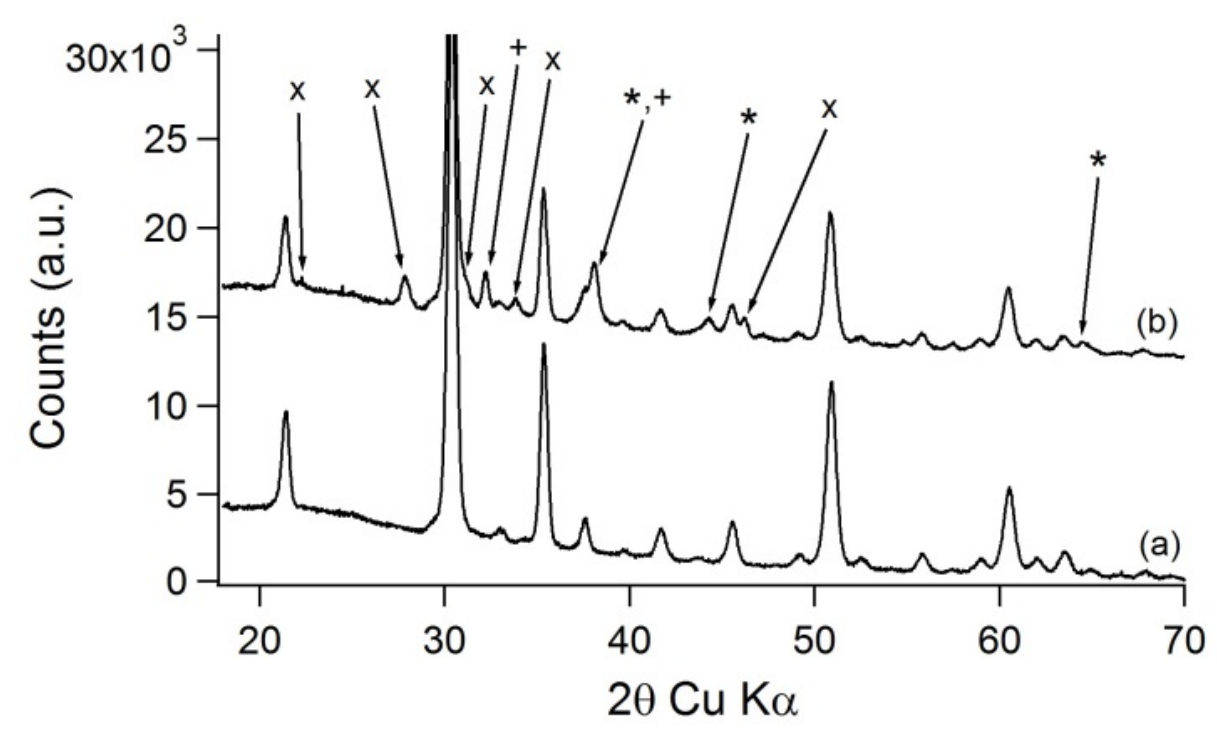

Figure 2. XRD diffractogram of the ITO substrate (a) and ITO-AgCat(ED) (deposited at $1.85 \mathrm{~V}$ for 1050 s); (b). Peak assignment : (*) metallic $\mathrm{Ag},(+) \mathrm{Ag}_{2} \mathrm{O}_{2},(\mathrm{x}) \mathrm{Ag}_{2} \mathrm{SO}_{4}$. Other conditions as in Figure 1.

\section{Electrocatalytic performance for water oxidation}

LSVs recorded with ITO-AgCat(ED) in sulfate buffer $0.010 \mathrm{M}$ at pH 2 (Figure S12 in Supporting Information) evidence the onset of the anodic current responsible for the water oxidation reaction at 1.6 $\mathrm{V}$ vs $\mathrm{Ag} / \mathrm{AgCl}(650 \mathrm{mV}$ overpotential). The behavior of the pristine ITO substrate is also reported to evidence the significant current increase due to the beneficial AgCat deposition. 
Concomitantly with the increase of the anodic current density at a potential higher than 1.6 vs $\mathrm{Ag} / \mathrm{AgCl}$, the evolution of gas bubbles is observed on the working electrode surface.

The best time and potential conditions for electrosynthesis, were found through an experimental design approach (with sulfate $10 \mathrm{mM}$, see Figure S2 in Supporting Information) and resulted $1050 \mathrm{~s}$ at $1.85 \mathrm{~V}$ vs $\mathrm{Ag} / \mathrm{AgCl}$, for which we recorded the highest current $\left(1 \mathrm{~mA} \mathrm{~cm}{ }^{-2}\right.$ at $850 \mathrm{mV}$ overpotential) and the lowest overpotential for the onset of water oxidation.
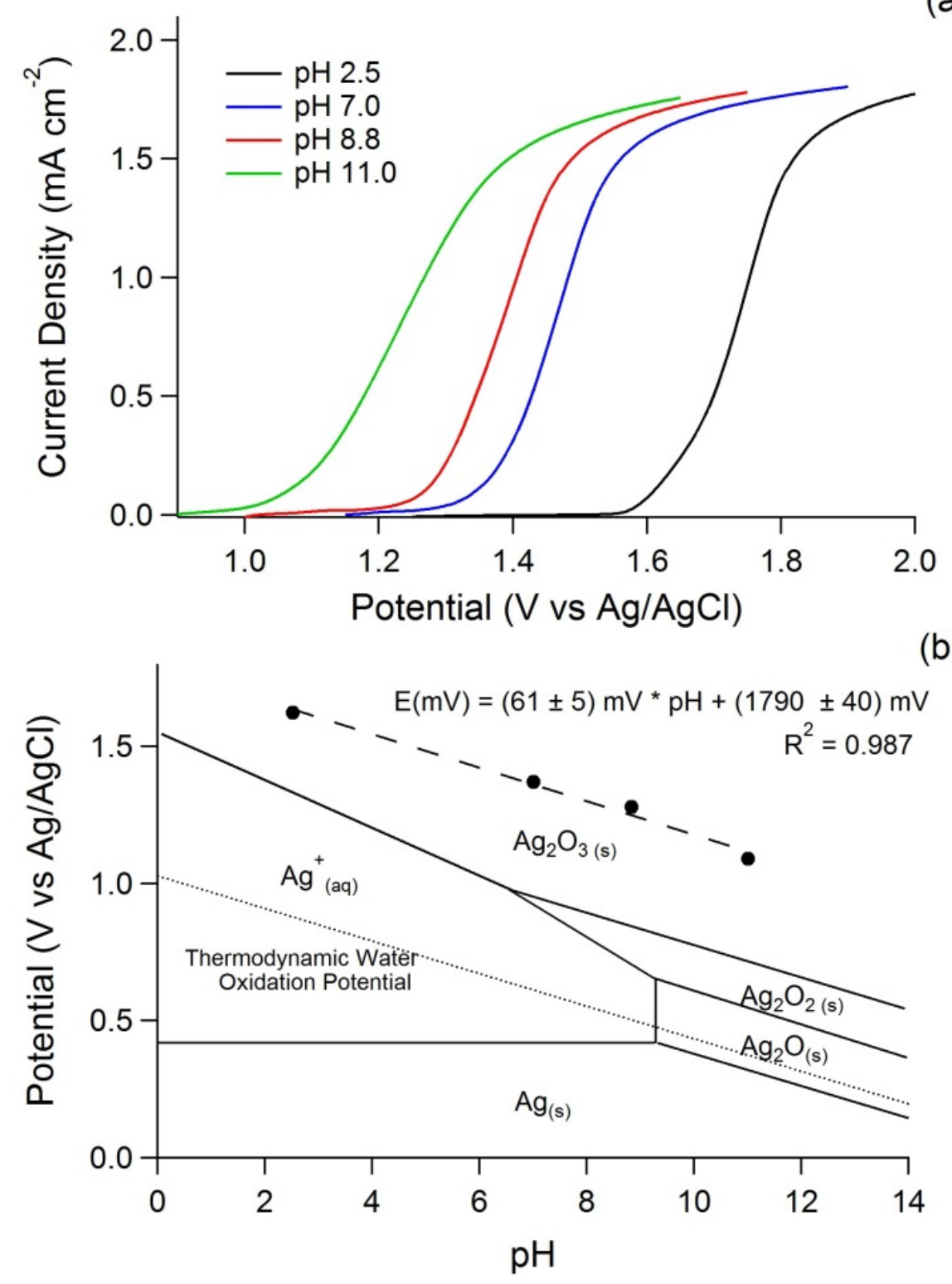

Figure 3. (a) LSVs at different $\mathrm{pH}$ values of ITO-AgCat(ED) as functions of the overpotential for the water oxidation (conditions: deposition at $1.85 \mathrm{~V}$ for $1050 \mathrm{~s}$ in $\mathrm{KNO}_{3} 100 \mathrm{mM}$, pH 2 and 
$\mathrm{AgNO}_{3} 1 \mathrm{mM}$ ); (b) $\mathrm{pH}$ dependence of the potential at which the current onset for water oxidation is observed (circles extrapolated from Figure 3a). The dotted line represents the $\mathrm{pH}$ dependence of the thermodynamic water oxidation potential.

The electrochemical performance of ITO-AgCat(ED) was tested at different $\mathrm{pH}$ values $(\mathrm{pH} 2.5,7$, 8.8, 11) and electrolyte compositions. The results are reported in Figure 3a.

The catalyst has comparable activity at several $\mathrm{pH}$ values tested. The potential at which the current onset is observed shifts with the $\mathrm{pH}$ with an almost Nernstian behavior (see Figure 3b). The current onsets are reported in Figure $3 \mathrm{~b}$ as points superimposed on the Pourbaix phase diagram of the Ag system, ${ }^{49}$ from which it is evident that water oxidation is always mediated by $\mathrm{Ag}(\mathrm{III})$. In the Pourbaix diagram $\mathrm{Ag}_{2} \mathrm{O}_{3}$ is dominant at acid $\mathrm{pH}$, whereas at $\mathrm{pH}$ higher than 8 , a new phase appears, $\mathrm{Ag}_{2} \mathrm{O}_{2}$, which is a mixed oxide of $\mathrm{Ag}(\mathrm{I})$ and $\mathrm{Ag}(\mathrm{III})$. The Pourbaix diagram shows that $\mathrm{Ag}(\mathrm{III})$ is the necessary thermodynamic condition for water oxidation, coherently with XRD evidence, which show that the mixed-valence oxide $\mathrm{Ag}_{2} \mathrm{O}_{2}$ is still present under the experimental conditions of XRD measurement. However, we have not any direct proof of the presence of $\mathrm{Ag}_{2} \mathrm{O}_{3}$.

Compared with $\mathrm{Co}-\mathrm{Pi}^{3}$ the overpotential for water oxidation is larger, approximately $600 \mathrm{mV}$. However, in view of the formation of an adaptive junction with wide band-gap semiconductors, this is a minor problem, as the valence band holes in $\mathrm{TiO}_{2}$ and hematite have potentials positive enough for the oxidation of the $\operatorname{Ag}(\mathrm{III}) / \operatorname{Ag}(\mathrm{I})$ couple. Referring to Figure 3b, we can break down this overpotential into two contributions. Since $\mathrm{Ag}(\mathrm{III})$ is necessary for water oxidation, there is an unavoidable contribution to the overpotential due to the thermodynamic difference between the redox potential of the $\operatorname{Ag}(\mathrm{III}) / \operatorname{Ag}(\mathrm{I})$ couple and the potential for water oxidation. This contribution is dictated by thermodynamic requirements, and cannot be improved changing either the co-catalyst morphology or crystallinity. The second contribution can be labeled as the "net overpotential", and represents the electrochemical energy needed to activate the $\operatorname{Ag}($ III) species for water oxidation. 
This second contribution to the overpotential can be minimized by improving the properties of AgCat.

The activity and stability of ITO-AgCat(ED) have been definitely confirmed in different solution

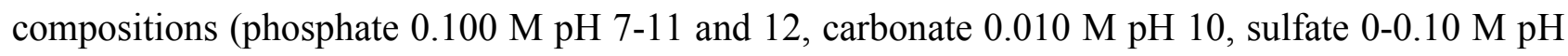
2-5, $\mathrm{NaOH} 0.1 \mathrm{M} \mathrm{pH} 13)$. Only when the concentration of the $\mathrm{SO}_{4}{ }^{2-}$ was higher than $0.010 \mathrm{M}$ at $\mathrm{pH}$ 5 and $0.100 \mathrm{M}$ at $\mathrm{pH} 2$, did we observe the reduction of the catalyst activity. A large sulfate concentration could favor surface complexes that are concurrent with surface hydroxyls involved in oxygen evolution.

On ITO-AgCat(ED) (deposited at $1.9 \mathrm{~V}$ for $1200 \mathrm{~s}$ ) - without any addition of $\mathrm{Ag}^{+}$to the electrolytic solution - we performed bulk electrolysis at $1.85 \mathrm{~V}$ vs $\mathrm{Ag} / \mathrm{AgCl}$ in the presence of a sulfate buffer $0.010 \mathrm{M}$ at $\mathrm{pH} 2$. We observed a current density around $1 \mathrm{~mA} \mathrm{~cm}^{-2}$ which lasted for almost $10 \mathrm{hrs}$, concomitantly with a copious evolution of $\mathrm{O}_{2}$ bubbles. Compared with Co-Pi (at $1.29 \mathrm{~V}$ versus NHE in $0.1 \mathrm{M}$ potassium phosphate electrolyte at $\mathrm{pH} 7.0$ containing $0.5 \mathrm{mM} \mathrm{Co}^{2+}$ ) the $\mathrm{AgCat}$ cocatalyst gives comparable current density. ${ }^{3}$ Performing electrolysis for 72 hrs we observed a TON $=$ 309, considering that $648 \mathrm{C}$ were measured while $2.1 \mathrm{C}$ were necessary for the catalyst electrodeposition. TOF remained constant and equal $4.3 \mathrm{~h}^{-1}$ during the whole experiment. During the catalyst synthesis gas bubbles formation was already observed, bearing witness to the fact that the charge responsible for the catalyst deposition was less than $2.1 \mathrm{C}$, and that the actual TON was probably higher than 309, and the TOF larger than $4.3 \mathrm{~h}^{-1}$. Definition of TON and TOF are available in a recent review. ${ }^{50}$ Then, blank and AgCat bulk electrolysis cycles demonstrate that the synthesized catalyst can perform the electrocatalytic oxidation of water and it is stable under a wide $\mathrm{pH}$ range and conditions of operation.

\section{Electrocatalytic mechanism}

We used EIS to get the faradaic resistance $R_{f}$ of the water oxidation reaction on ITO-AgCat(ED) thin films. The plot of $\log \left(\mathrm{R}_{\mathrm{f}}^{-1}\right) v s$ the electrochemical potential E yields a Tafel plot. ${ }^{51}$ The slope of 
the curve obtained can be used to examine the mechanism of the water oxidation reaction. In the potential range studied we observed variable and high Tafel slopes (> $150 \mathrm{mV} \mathrm{dec}{ }^{-1}$, Figure 4). This behavior has been observed and explained by Bediako et al. ${ }^{48}$ in terms of joint control of the reaction rate by electrocatalytic activity, proton-electron hopping and proton diffusion. In particular the Tafel slope can be very high (i.e. almost flat trend of $\log \left(\mathrm{R}_{\mathrm{f}}^{-1}\right)$ vs E, see inset of Figure 4) at an intermediate $\mathrm{pH}$ buffer concentration, where the reaction switches from electrocatalytic and protonelectron hopping control to joint electrocatalytic, proton-electron hopping and proton diffusion control. For AgCat it is not possible to increase the buffer concentration (sulfate for buffering at $\mathrm{pH}$ 2), since the increase from $10 \mathrm{mM}$ to $100 \mathrm{mM}$ leads to a current decrease by two orders of magnitude. We formerly attributed this effect to catalyst inactivation by surface precipitation induced by the $\mathrm{SO}_{4}{ }^{2-}$ anion.

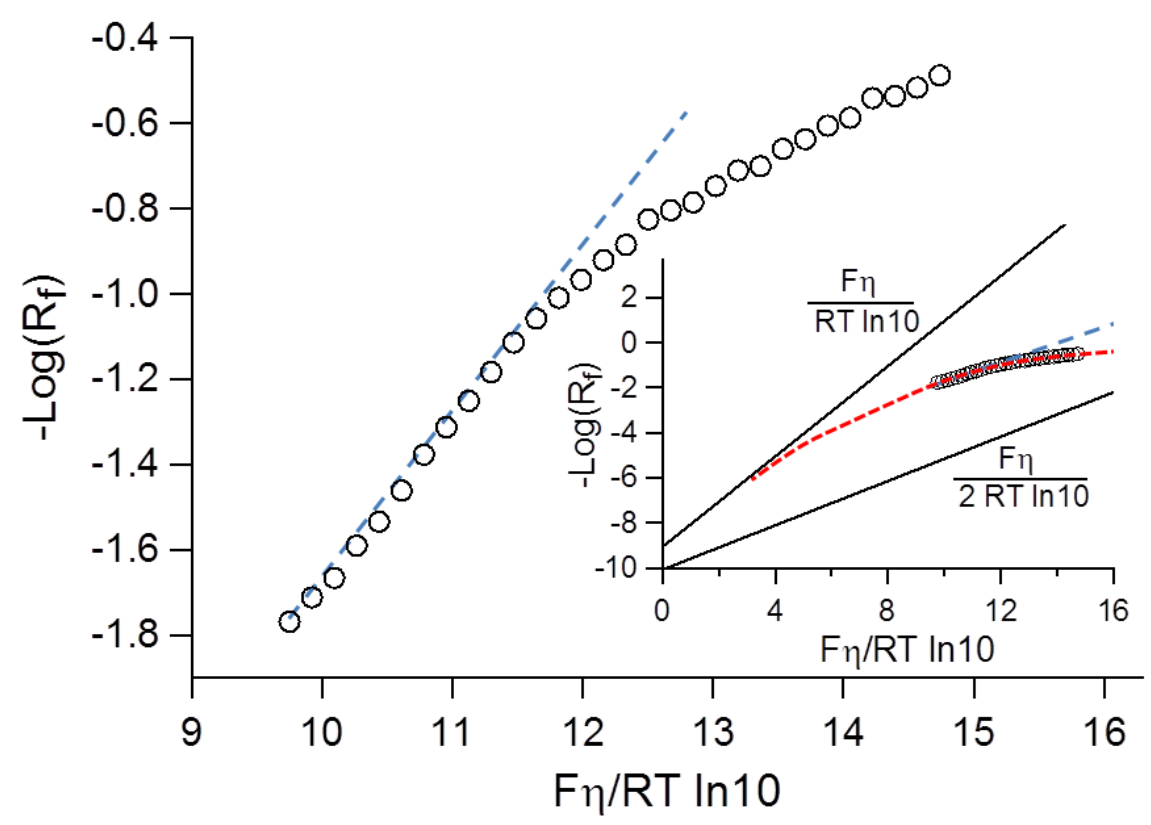

Figure 4. Tafel plot of the ITO-AgCat(ED) (deposited at $1.9 \mathrm{~V}$ for $1200 \mathrm{~s}$ ), measurements with EIS at $\mathrm{pH} 2$ (see text). The value of the observed slope (dashed line) at low overpotentials is 149 $\mathrm{mV} /$ decade. Inset: plausible collocation of Tafel data obtained in the present study in the theoretical framework proposed in ref. ${ }^{48}$ 
This experiment demonstrated that AgCat behaves like other porous thin film catalysts, in which the reaction rate is controlled by multiple factors including the electron transfer, proton hopping and diffusion kinetics.

\section{Photoelectrocatalytic performance on $\mathrm{TiO}_{2}$ and $\alpha-\mathrm{Fe}_{2} \mathrm{O}_{3}$ electrodes}

Under illumination and with $\mathrm{TiO}_{2}$, the photocurrent in the presence of $\mathrm{AgCat}$ is lower than the one recorded without $\mathrm{AgCat}$ at potentials lower than $1.1 \mathrm{v}$ vs $\mathrm{Ag} / \mathrm{AgCl}$ (compare Figure 5 continuous lines and Figure S5). This potential (1.1 V at $\mathrm{pH} 7)$ corresponds to the standard redox potential of the couple $\mathrm{Ag}_{2} \mathrm{O}_{3} / \mathrm{Ag}(\mathrm{I})$. The $\mathrm{AgCat}(\mathrm{PED})$ on $\mathrm{TiO}_{2}$ shows the current onset at $1.4 \mathrm{~V}$ vs $\mathrm{Ag} / \mathrm{AgCl}$ at pH 7 (see Figure 5), in analogy with the observation made in the absence of $\mathrm{TiO}_{2}$ (Figure $\mathrm{S} 12$ in Supporting Information). The small current peak appreciable in the dark for AgCat(PED) on $\mathrm{TiO}_{2}$ is due to the unavoidable presence of residual metallic $\mathrm{Ag}$ which is formed from $\mathrm{AgCat}$ decomposition during the time needed to i) wash the electrochemical cell after the electrosynthesis and ii) change the electrolyte, which must be free from $\mathrm{Ag}^{+}$for all the characterization measurements performed. Under illumination (measurement carried out just after the measurement in the dark) the peak is no longer visible. It is worth noting that at the same $\mathrm{pH}$ the Co-Pi catalyst on the same $\mathrm{TiO}_{2}$ substrate showed complete quenching of the photocurrent.

The electrochemical and photoelectrochemical performance of bare $\mathrm{TiO}_{2}$ and $\alpha-\mathrm{Fe}_{2} \mathrm{O}_{3}$, and that of Co-Pi coupled on them, were extensively investigated. The results are mostly reported in Supporting Information as reference data with which AgCat properties are here compared. The poor performance of Co-Pi, coupled to $\mathrm{TiO}_{2}$ and hematite used in our tests, as evidenced by the photocurrent (Figure S5 and S8) and, most importantly, by the negligible $\mathrm{O}_{2}$ production in photoelectrochemical conditions (Table S1 in Supporting Information), indicate that an excellent electrocatalyst, such as Co-Pi, could not be suitable for coupling with wide band-gap semiconductors. In the case of Co-Pi the abatement of photocurrent recorded on $\mathrm{TiO}_{2}-\mathrm{Co}-\mathrm{Pi}$ (Figure S5) electrodes and the null $\mathrm{O}_{2}$ production under irradiation observed for $\alpha-\mathrm{Fe}_{2} \mathrm{O}_{3}-\mathrm{Co}-\mathrm{Pi}$ electrodes 
under our experimental conditions (Table S1 in Supporting Information) have to be ascribed not only to an increased charge carrier recombination promoted by oxidized Co species, but also to the production of intermediate species that adsorb on $\mathrm{TiO}_{2}$ and $\alpha-\mathrm{Fe}_{2} \mathrm{O}_{3}$, and, there, act as recombination surface sites. In a hybrid system with graphene, in which Co-Pi was deposited on $\mathrm{TiO}_{2}$, considerable amounts of $\mathrm{H}_{2} \mathrm{O}_{2}$ were detected in the presence of phosphate in solution. ${ }^{52}$ Phosphate ions bind to the $\mathrm{TiO}_{2}$ surface, as do fluoride ions, ${ }^{53-54}$ impeding the formation of adsorbed surface peroxide ions that recombine charge carriers ${ }^{55}$ and impede the formation of molecular oxygen. This explanation was also given for the low faradaic efficiencies observed with $\mathrm{Co}-\mathrm{Pi} / \mathrm{WO}_{3}{ }^{25}$ Moreover the lack of resonance between $\mathrm{Co}-\mathrm{Pi}$ and $\mathrm{TiO}_{2}$ or $\alpha-\mathrm{Fe}_{2} \mathrm{O}_{3}$ valence band could impede a fast and selective hole transfer. As the oxidizing potential of the couple $\mathrm{Ag}(\mathrm{III}) / \mathrm{Ag}(\mathrm{I})$ is larger than that of $\mathrm{Co}(\mathrm{III}) / \mathrm{Co}(\mathrm{II})$, this could improve the resonance with electronic states in the semiconductor valence band. Thus, in the case of AgCat, either hole transfer becomes more efficient or recombination of charge carriers is more inhibited. 


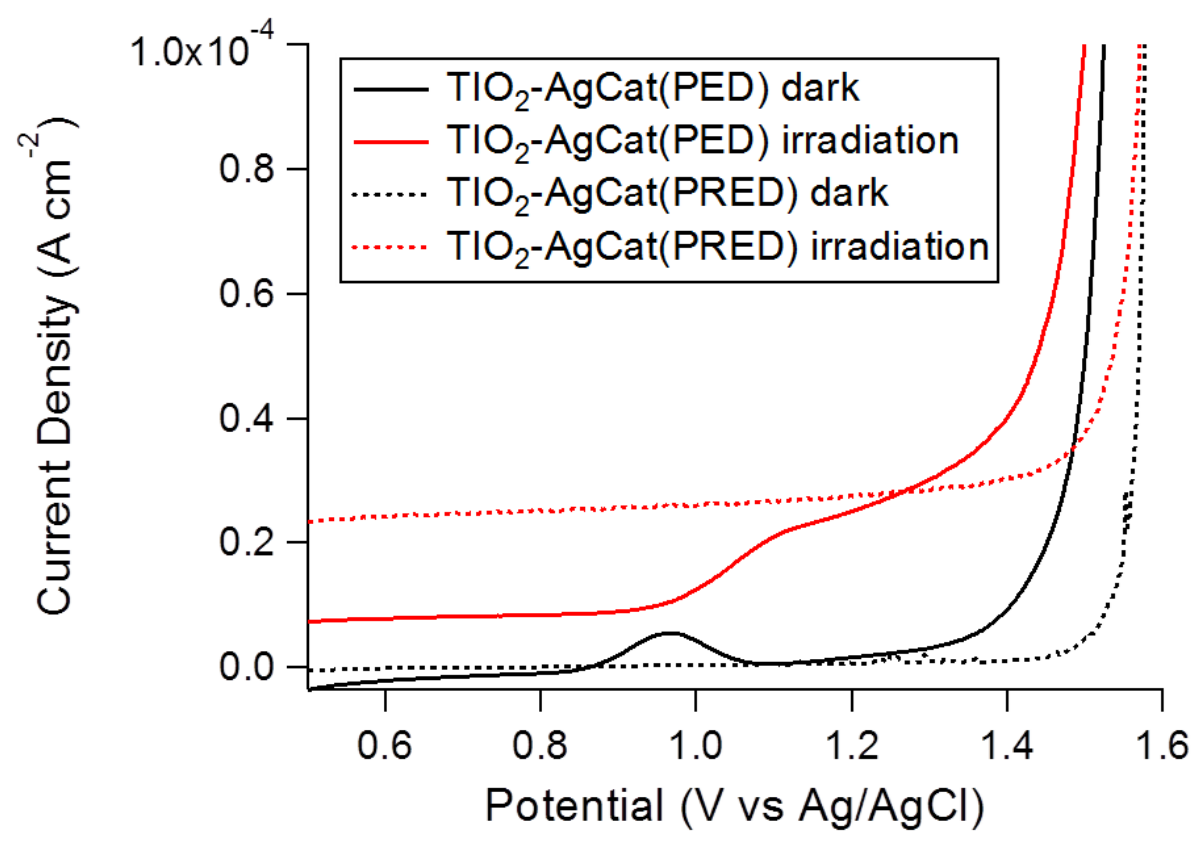

Figure 5. Anodic LSVs of $\mathrm{TiO}_{2}-\mathrm{AgCat}(\mathrm{PED})$ and $\mathrm{TiO}_{2}-\mathrm{AgCat}(\mathrm{PRED})$ electrodes in the dark and upon irradiation in $\mathrm{KNO}_{3} 0.1 \mathrm{M}$ at $\mathrm{pH} 7$

The PRED synthesis of AgCat increases the photocurrent. The electrode $\mathrm{TiO}_{2}-\mathrm{AgCat}(\mathrm{PRED})$ can sustain photocurrent up to $2.510^{-5} \mathrm{~A} \mathrm{~cm}^{-2}$ in the potential window $0.5-1.2 \mathrm{~V}$ vs $\mathrm{Ag} / \mathrm{AgCl}$ at $\mathrm{pH} 7$, a value significantly larger compared to both bare $\mathrm{TiO}_{2}$ and pristine $\mathrm{TiO}_{2}-\mathrm{AgCat}$ (Figure 5, dashed lines).

Nonetheless, only at high overpotential $(\eta=1080 \mathrm{mV})$ and with low faradaic efficiency $(20 \%)$ did we measure the $\mathrm{O}_{2}$ evolution on $\mathrm{TiO}_{2}$-AgCat(PRED) electrodes. Even if the oxygen production under irradiation $\left(0.17 \pm 0.02 \mu \mathrm{mol} \mathrm{h}^{-1}\right)$ was significantly larger than in dark conditions $(0.42 \pm 0.02$ $\mu \mathrm{mol} \mathrm{h}{ }^{-1}$ ), the high overpotential needed and the low faradaic efficiency obtained coupling AgCat to $\mathrm{TiO}_{2}$ reveal that $\mathrm{TiO}_{2}$ itself is a worse photocatalyst for water oxidation, as AgCat (and Co-Pi) alone can sustain $\mathrm{O}_{2}$ production under electrochemical conditions.

The poor results obtained with $\mathrm{TiO}_{2}$ suggested to us to couple AgCat to $\alpha-\mathrm{Fe}_{2} \mathrm{O}_{3}$, capable by itself to oxidize water, ${ }^{1,56}$ and employed with Co-Pi as co-catalyst several times. ${ }^{13,15-19,24}$ We did the 
experiments on $\alpha-\mathrm{Fe}_{2} \mathrm{O}_{3}$ (PRED) because on $\alpha-\mathrm{Fe}_{2} \mathrm{O}_{3}(\mathrm{ED})$ the photocurrent is negligible in the potential window explored (Figure S6 in Supporting Information). The anodic LSV on $\alpha-\mathrm{Fe}_{2} \mathrm{O}_{3}$ (PRED) in $\mathrm{NaOH}$ 0.1 $\mathrm{M}$ in the dark and under irradiation is reported in Figure S7. Hematite (PRED) shows photocurrent density of $4 \cdot 10^{-5} \mathrm{~A} \mathrm{~cm}^{-2}$ between 0.75 and $0.95 \mathrm{~V}$ vs $\mathrm{Ag} / \mathrm{AgCl}$. The current density observed in the LSV experiment is responsible for $\mathrm{O}_{2}$ evolution as was confirmed by electrolysis cycles at $0.7 \mathrm{~V}, 0.8 \mathrm{~V}$ and $0.9 \mathrm{~V}$ vs $\mathrm{Ag} / \mathrm{AgCl}$ (overpotentials $450 \mathrm{mV}, 550 \mathrm{mV}$ and $650 \mathrm{mV}$, respectively), in the dark and upon irradiation, in which gas chromatographic detection of $\mathrm{O}_{2}$ was performed. We measured $\mathrm{O}_{2}$ evolution on $\alpha-\mathrm{Fe}_{2} \mathrm{O}_{3}$ (PRED) above $450 \mathrm{mV}$ overpotential (Figure 6). At $550 \mathrm{mV}$ overpotential we recorded $0.37 \mu \mathrm{mol} \mathrm{h}^{-1}$ in the dark and $0.74 \mu \mathrm{mol} \mathrm{h} \mathrm{h}^{-1}$ under irradiation (2-fold), while at $650 \mathrm{mV}$ overpotential we observed a larger production, especially under irradiation, with a 5-fold increase. The increase of overpotential increases also the faradaic efficiency up to $90 \%$ at $650 \mathrm{mV}$ overpotential (Figure 6). It is noteworthy that absolute values of photocurrents and $\mathrm{O}_{2}$ production basically depend on the material synthetic route. ${ }^{56}$ Recently, larger photocurrents have been obtained with $\alpha-\mathrm{Fe}_{2} \mathrm{O}_{3}$ controlling substitutional doping ${ }^{57-58}$ and morphology, ${ }^{59-60}$ in combination with specific techniques to address electrochemical losses at the surface, ${ }^{61}$ including the addition of catalysts, such as $\mathrm{Ni}(\mathrm{OH})_{2}$ or $\beta-\mathrm{FeOOH},{ }^{58-59}$ and $\mathrm{Co}-\mathrm{Pi} .{ }^{13,15,18,62}$ Thanks to the above-mentioned synthetic routes, these materials have a marked intrinsic ability to separate photogenerated charge carriers compared with hematite obtained from electrosynthesis. 


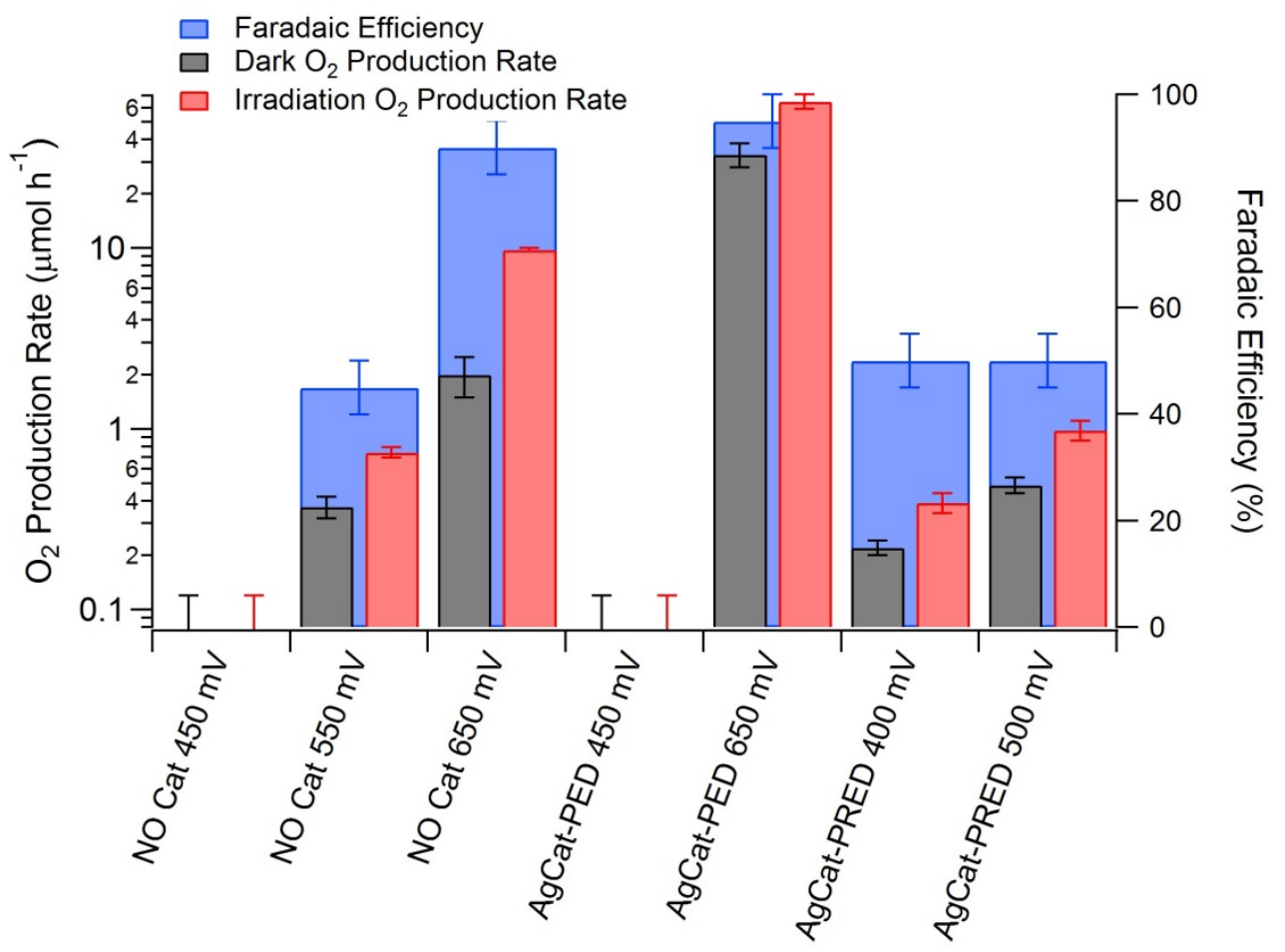

Figure $6 . \mathrm{O}_{2}$ production rate (logarithmic scale) and faradaic efficiency in the dark and upon irradiation for $\alpha-\mathrm{Fe}_{2} \mathrm{O}_{3}$ (PRED) electrodes without and with $\mathrm{AgCat}$ in $\mathrm{NaOH} 0.1 \mathrm{M}$ at different overpotentials. Actual values can be consulted in Table $\mathrm{S} 2$ in Supporting Information.

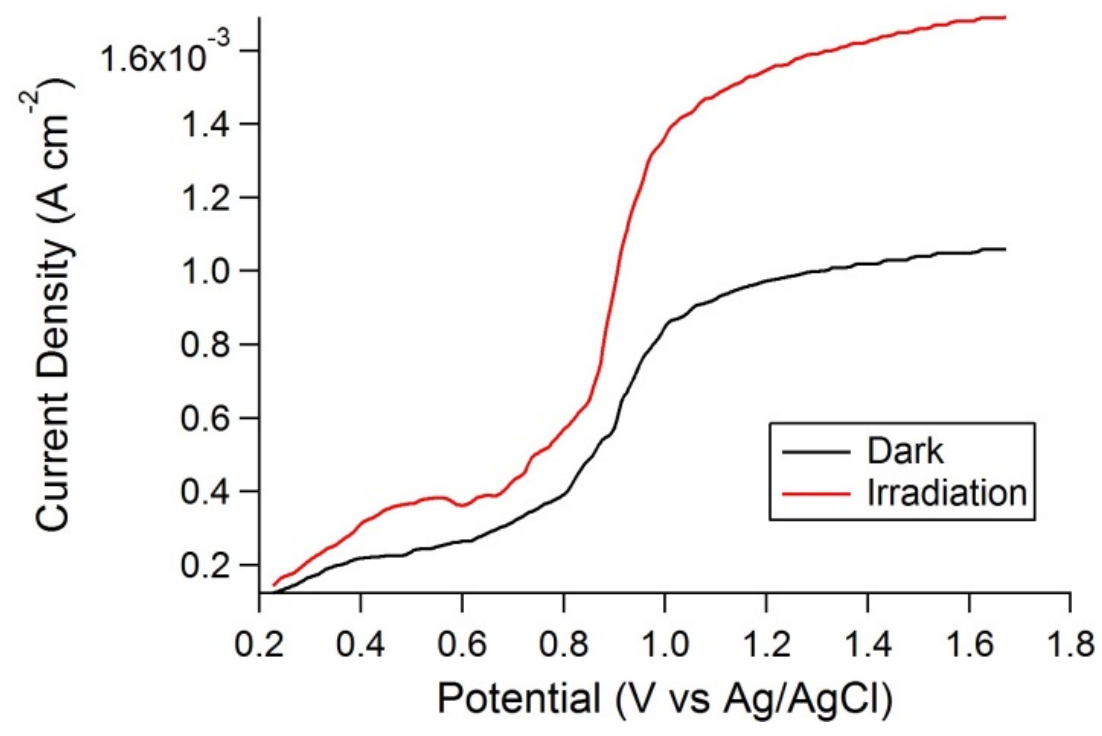


Figure 7. Anodic LSVs for an $\alpha-\mathrm{Fe}_{2} \mathrm{O}_{3}$ (PRED)-AgCat(PED) electrode in the dark and under irradiation in $\mathrm{NaOH} 0.1 \mathrm{M}$ at $\mathrm{pH} 13$.

The coupling of AgCat (PED) with $\alpha-\mathrm{Fe}_{2} \mathrm{O}_{3}$ (PRED) results in large photocurrent density, which increases through increasing anodic bias, up to $800 \mu \mathrm{A} \mathrm{cm}^{-2}$ around $1.5 \mathrm{~V}$ vs $\mathrm{Ag} / \mathrm{AgCl}$ (Figure 7), while at $0.9 \mathrm{~V}$ vs $\mathrm{Ag} / \mathrm{AgCl}\left(650 \mathrm{mV}\right.$ overpotential) the photocurrent density is around $500 \mu \mathrm{A} \mathrm{cm}{ }^{-2}$ (Figure 8), and at $0.25 \mathrm{~V}$ vs $\mathrm{Ag} / \mathrm{AgCl}\left(0 \mathrm{mV}\right.$ overpotential) the photocurrent density is $34 \mu \mathrm{A} \mathrm{cm}{ }^{-2}$ (Figure 7), these results are very close to the highest values achievable through wet chemistry synthesis. ${ }^{56}$

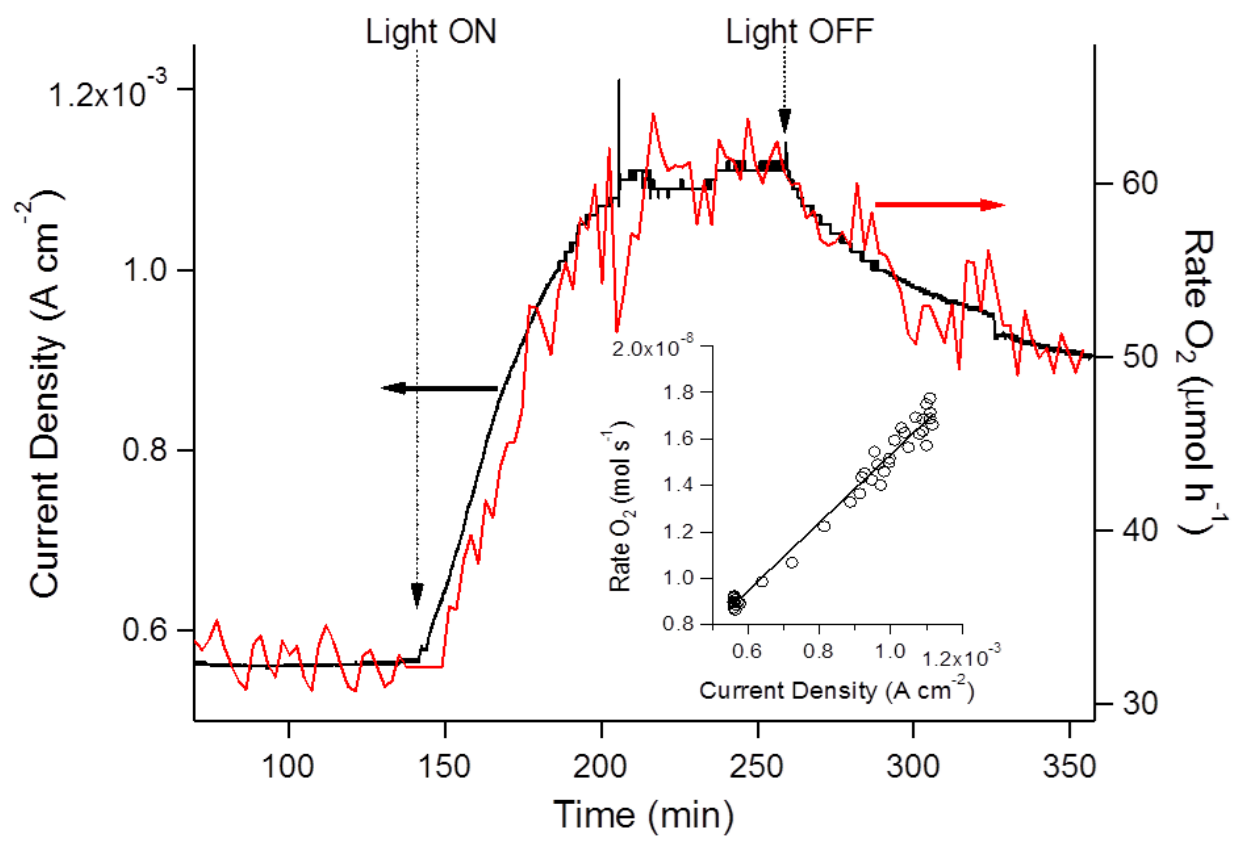

Figure 8. Experimental current density and the $\mathrm{O}_{2}$ evolution rate as a function of electrolysis time. Conditions: $\mathrm{Fe}_{2} \mathrm{O}_{3}$ (PRED)-AgCat(PED) at overpotential $650 \mathrm{mV} \mathrm{NaOH} 0.1 \mathrm{M}(\mathrm{pH}$ 13). Main picture: experimental measurements. Inset: correlation of the measurements, with slope related to the faradaic efficiency.

Through the bulk electrolysis at $650 \mathrm{mV}$ overpotential (Figure 8), we wanted to i) assess current density in the dark and upon irradiation; ii) assess $\mathrm{O}_{2}$ production in the dark and under irradiation, 
and faradaic efficiencies; and iii) to verify if irradiation increases current density and $\mathrm{O}_{2}$ production. We verified hypothesis iii), and, additionally, we observed that the photocurrent tended to increase with time. We observed that only after $50 \mathrm{~min}$ is the steady-state photocurrent attained, and, moreover, when irradiation is interrupted (minute 260), there is a long transient in which the current density remains higher than before irradiation. Even after 100 minutes in the dark, the current density is $300 \mu \mathrm{A} \mathrm{cm}^{-2}$ higher than its initial value. These phenomena are observed also in the case of hematite alone (Figure S9 in Supporting Information), and, therefore, can be attributed to potential and light-driven modifications of the semiconductor, which improve the overall performance of the material. These modifications are also responsible for small changes of the ATR-FTIR spectra $\alpha-\mathrm{Fe}_{2} \mathrm{O}_{3}(\mathrm{PRED})$ after irradiation for $2 \mathrm{~h}$ at $650 \mathrm{mV}$ overpotential in $\mathrm{NaOH} 0.1 \mathrm{M}$ (Figure S 11 in Supporting Information).

Modifications of the structure of irradiated hematite electrodes under anodic electrochemical bias were detected in near-edge X-ray absorption fine structure (NEXAFS) studies. ${ }^{63-64}$ The nature of these modifications was not fully understood, and has been tentatively assigned in literature to the presence of oxidized Fe species, such as $\mathrm{Fe}(\mathrm{IV})$ or $\mathrm{Fe}(\mathrm{V}){ }^{63-64}$ This suggestion is consistent with our results, since the modifications occur during water oxidation under irradiation, and, therefore, the presence of oxidized Fe species can be justified. Moreover, the modification of surface species, including $\mathrm{Fe}(\mathrm{IV})$ and $\mathrm{Fe}(\mathrm{V})$, is in agreement with the observation that the larger water oxidation current, observed when irradiation is stopped, occurs both in the presence and in the absence of AgCat co-catalyst (see Figure 8, Figure S9 and S10 in Supporting Information). This modification is not instantaneous, and under our experimental setup requires approximately 50 minutes to be completed. As a consequence, it could not be revealed or studied with techniques operating at shorter timescales, i.e. LSV or chopped light voltammetry commonly used. The evolution of aqueous $\mathrm{FeO}_{4}{ }^{2-}$ can be ruled out instead, since it cannot be experimentally revealed even after 20 hours of electrolysis at $650 \mathrm{mV}$ overpotential. The experimental detection limit corresponded to 
$\mathrm{FeO}_{4}{ }^{2-}$ production of $1.5 \mathrm{nmol} \mathrm{h}{ }^{-1}$. Conversely, all these experiments demonstrated also that AgCat is stable under irradiation.

The photocurrent observed during the bulk electrolysis experiment of Figure 8 is responsible for $\mathrm{O}_{2}$ evolution with 90-100\% faradaic efficiency as reported in Figure 6 and Table S2 in Supporting Information, thus confirming that the absorbing semiconductor plays its own role in addition to the co-catalyst. $\mathrm{O}_{2}$ production achieved with $\alpha-\mathrm{Fe}_{2} \mathrm{O}_{3}(\mathrm{PRED})-\mathrm{AgCat}(\mathrm{PED})$ at $650 \mathrm{mV}$ overpotential is noteworthy when compared with the other semiconductor specimens tested in the present work, both in the dark and under irradiation. The comparison of bare hematite, Co-Pi on hematite (Table S1 in Supporting Information) and AgCat on hematite (Figure 6 and Table S2 in Supporting Information) reveals that at $650 \mathrm{mV}$ overpotential $\mathrm{Fe}_{2} \mathrm{O}_{3}(\mathrm{PRED})-\mathrm{AgCat}(\mathrm{PED})$ shows in the dark a 40-fold increase compared with $\alpha-\mathrm{Fe}_{2} \mathrm{O}_{3}$ (PRED)-Co-Pi, and 24-fold increase compared with $\alpha$ $\mathrm{Fe}_{2} \mathrm{O}_{3}(\mathrm{PRED})$; under irradiation there is a 6-fold increase compared with $\alpha-\mathrm{Fe}_{2} \mathrm{O}_{3}(\mathrm{PRED})$, while $\mathrm{O}_{2}$ production on $\alpha-\mathrm{Fe}_{2} \mathrm{O}_{3}(\mathrm{PRED})-\mathrm{Co}-\mathrm{Pi}$ was not detectable.

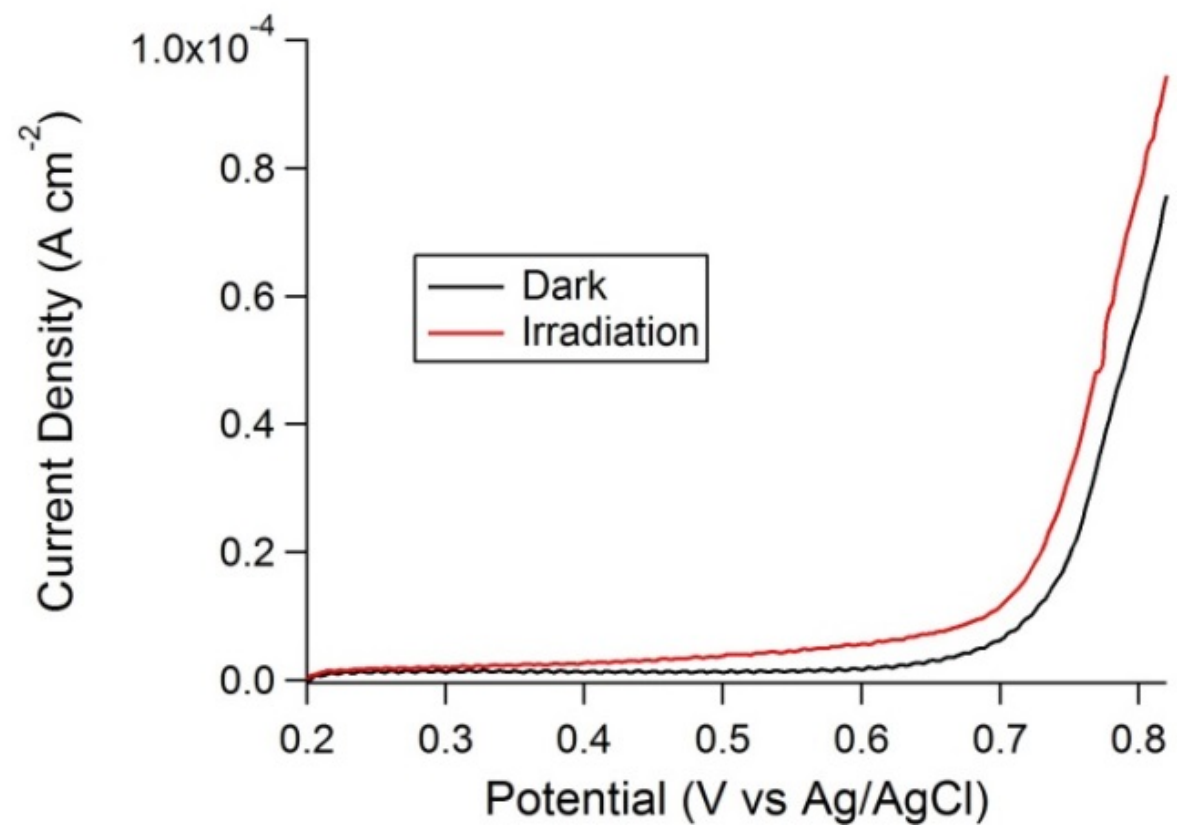

Figure 9. Anodic LSVs for a $\alpha-\mathrm{Fe}_{2} \mathrm{O}_{3}$ (PRED)-AgCat (PRED) electrode in the dark and under irradiation in $\mathrm{NaOH} 0.1 \mathrm{M}$ at $\mathrm{pH} 1$ 
These results are further improved in terms of overpotential by the deposition of AgCat (PRED) on $\alpha-\mathrm{Fe}_{2} \mathrm{O}_{3}$ (PRED) (see Figure 9 and Table S2 in Supporting Information). The photocurrent can be appreciated at $0.300 \mathrm{~V}$ vs $\mathrm{Ag} / \mathrm{AgCl}$, corresponding to an overpotential as low as $60 \mathrm{mV}$. The material $\mathrm{TiO}_{2}$-AgCat(PRED) showed an analogous improvement of photocurrents. At this low overpotential, however, we did not detect molecular oxygen evolution. Whilst the hybrid system $\alpha-$ $\mathrm{Fe}_{2} \mathrm{O}_{3}$ (PRED)-AgCat(PED) did not exhibit a significant $\mathrm{O}_{2}$ production below $0.7 \mathrm{~V}$ vs $\mathrm{Ag} / \mathrm{AgCl}$ $(\eta=450 \mathrm{mV})$, a better performance was achieved with $\alpha-\mathrm{Fe}_{2} \mathrm{O}_{3}(\mathrm{PRED})-\mathrm{AgCat}(\mathrm{PRED})$, which gave $\mathrm{O}_{2}$ production already at to $0.65 \mathrm{~V}$ vs $\mathrm{Ag} / \mathrm{AgCl}(\eta=400 \mathrm{mV})$ with a $50 \%$ faradaic efficiency and a significant increase under irradiation (Figure 6). Somehow we observed faradaic efficiency lower than $100 \%$. This implies that the oxidative current is due to oxidation of water to species other than molecular oxygen, because the material itself is not degraded, as supported by exhaustive electrolysis.

AgCat forms a suitable interface with hematite, allowing a more directional charge transfer with less recombination. Even though absolute performance in terms of photocurrent is not excellent compared with other reports, ${ }^{18,57-58,60}$ in which hematite was doped or prepared through non-wet chemistry methods, nonetheless the values here reported are at the upper limit for wet chemistry synthesized hematite. In the light of the evidence here reported, we envisage that deposition of AgCat on hematite prepared by non-wet chemistry methods would give higher photocurrents. ${ }^{57}$

\section{CONCLUSION}

The water oxidation catalyst based on mixed $\mathrm{Ag}(\mathrm{I}, \mathrm{III})$ oxide (AgCat) works at a moderate overpotential and is suitable for the coupling with wide band-gap semiconductors. The AgCat cocatalyst is produced through electrodeposition in the form of surface particles. The current density was optimized with respect to electrosynthesis time and potential. AgCat activity and stability have been demonstrated in a wide range of $\mathrm{pH}(2-13)$ and solution compositions (phosphate, sulfate). The current densities obtained with AgCat are comparable with Co-Pi and can be sustained for long 
times, as demonstrated in dark bulk electrolysis experiments without $\operatorname{Ag}(\mathrm{I})$ in solution. Semiconductor substrates made of different materials $\left(\mathrm{TiO}_{2}\right.$ and hematite) and prepared through different techniques, when coupled with oxygen evolving catalysts, play a crucial role in determining the overall performance of the hybrid materials. The overpotential is rather large in the case of AgCat, because of oxidizing conditions required to generate $\mathrm{Ag}(\mathrm{III})$, which is the active species in the water oxidation reaction. Nevertheless, AgCat coupled with hematite produces considerable photocurrents and $\mathrm{O}_{2}$ production with high faradaic efficiency.

\section{ASSOCIATED CONTENT}

Supporting Information. The following files are available free of charge.

$\mathrm{pH}-\mathrm{E}_{\mathrm{h}}$ diagrams for $\mathrm{Ag}$ in the presence of sulfate $10 \mathrm{mM}$ and $100 \mathrm{mM}$ (Figure $\mathrm{S} 1$ ); the optimization of the current density as a function of electrosynthesis time and potential obtained through an experimental design approach (Figure S2); chronopotentiometry (Figure S3) and cyclic voltammetry (Figure S4) of pristine $\mathrm{TiO}_{2}$ electrodes; anodic $\mathrm{LSV}$ of $\mathrm{TiO}_{2}$-Co-Pi (Figure S5); linear sweep voltammetry of electrodeposited $\alpha-\mathrm{Fe}_{2} \mathrm{O}_{3}, \alpha-\mathrm{Fe}_{2} \mathrm{O}_{3}$ (PRED), and $\alpha-\mathrm{Fe}_{2} \mathrm{O}_{3}$ (PRED)-Co-Pi in the dark and under irradiation (Figure $\mathrm{S} 6, \mathrm{~S} 7$ and $\mathrm{S} 8$, respectively); their $\mathrm{O}_{2}$ production rate and faradaic efficiency in the dark and under irradiation (Table S1); current density and $\mathrm{O}_{2}$ evolution rate as functions of the time for $\alpha-\mathrm{Fe}_{2} \mathrm{O}_{3}$ (PRED) (Figure S9); the $\mathrm{O}_{2}$ production rate and faradaic efficiency in the dark and under irradiation for bare and AgCat-modified $\alpha-\mathrm{Fe}_{2} \mathrm{O}_{3}$ electrodes (Table S2); LSVs and ATR-FTIR spectra of $\alpha-\mathrm{Fe}_{2} \mathrm{O}_{3}$ (PRED) electrodes before and after electrolysis experiments, which were carried out at positive applied bias and under irradiation (Figure S10 and S11); LSV of AgCat on ITO (Figure S12); and overpotential values for water oxidation and photocurrent density for $\mathrm{TiO}_{2}$ (Table S3) and hematite (Table S4) electrodes. (SI.PDF)

\section{AUTHOR INFORMATION}

\section{Corresponding Author}


*e-mail: claudio.minero@unito.it. Tel.: +39 011670 8449. Fax: +39 0116705242.

\section{ACKNOWLEDGMENT}

The financial support from project Ricerca Locale - Torino University - the project

PHOTORECARB - Progetti di Ateneo/CSP 2012 - Call 03 - Università di Torino \& Compagnia di

S.Paolo - is gratefully acknowledged. The authors thank Susanna Lombardo for her help in the

synthesis of hematite electrodes and related electrochemical measurements, and Gianluca Fiore for

his help with XRD experiments.

\section{REFERENCES}

1. $\quad$ Grätzel, M. Photoelectrochemical Cells. Nature 2001, 414, 338-344.

2. Cao, R.; Lai, W.; Du, P. Catalytic Water Oxidation at Single Metal Sites. Energy Environ. Sci. 2012, 5, 8134-8157.

3. Kanan, M. W.; Nocera, D. G. In Situ Formation of an Oxygen-evolving Catalyst in Neutral Water Containing Phosphate and $\mathrm{Co}^{2+}$. Science 2008, 321, 1072-1075.

4. Chatchai, P.; Murakami, Y.; Kishioka, S.-y.; Nosaka, A. Y.; Nosaka, Y. Efficient Photocatalytic Activity of Water Oxidation Over $\mathrm{WO}_{3} / \mathrm{BiVO}_{4}$ Composite Under Visible Light Irradiation. Electrochim. Acta 2009, 54, 1147-1152.

5. $\quad$ Ding, C.; Shi, J.; Wang, D.; Wang, Z.; Wang, N.; Liu, G.; Xiong, F.; Li, C. Visible Light Driven Overall WaterSplitting Using Cocatalyst/BiVO 4 Photoanode With Minimized Bias. Phys. Chem. Chem. Phys. 2013, 15, 4589-4595.

6. Nakagawa, T.; Beasley, C. A.; Murray, R. W. Efficient Electro-oxidation of Water near Its Reversible Potential by a Mesoporous IrOx Nanoparticle Film. J. Phys. Chem. C 2009, 113, 12958-12961.

7. Nakagawa, T.; Bjorge, N. S.; Murray, R. W. Electrogenerated IrOx Nanoparticles as Dissolved Redox Catalysts for Water Oxidation. J. Am. Chem. Soc. 2009, 131, 15578-15579.

8. Moir, J.; Soheilnia, N.; O’Brien, P.; Jelle, A.; Grozea, C. M.; Faulkner, D.; Helander, M. G.; Ozin, G. A. Enhanced Hematite Water Electrolysis Using a 3D Antimony-doped Tin Oxide Electrode. ACS Nano 2013, 7, 4261-74.

9. Bediako, D. K.; Surendranath, Y.; Nocera, D. G. Mechanistic Studies of the Oxygen Evolution Reaction Mediated by a Nickel-Borate Thin Film Electrocatalyst. J. Am. Chem. Soc. 2013, 135, 3662-3674.

10. Lutterman, D. A.; Surendranath, Y.; Nocera, D. G. A Self-healing Oxygen-evolving Catalyst. J. Am. Chem. Soc. 2009, 131, 3838-3839.

11. Yang, J.; Wang, D.; Han, H.; Li, C. Roles of Cocatalysts in Photocatalysis and Photoelectrocatalysis. Acc. Chem. Res. 2013, 46, 1900-1909.

12. Steinmiller, E. M. P.; Kyoung-Shin, C. Photochemical Deposition of Cobalt-based Oxygen Evolving Catalyst on a Semiconductor Photoanode for Solar Oxygen Production. Proc. Natl. Acad. Sci. U.S.A. 2009, 106, 20633.

13. McDonald, K. J.; Choi, K.-S. Photodeposition of Co-Based Oxygen Evolution Catalysts on $\alpha-\mathrm{Fe}_{2} \mathrm{O}_{3}$ Photoanodes. Chem. Mater. 2011, 23, 1686-1693.

14. Young, E. R.; Costi, R.; Paydavosi, S.; Nocera, D. G.; Bulovic, V. Photo-assisted Water Oxidation with Cobalt-based Catalyst Formed from Thin-Film Cobalt Metal on Silicon Photoanodes. Energy Environ. Sci. 2011, 4, 2058-2061.

15. Zheng, J. Y.; Son, S. I.; Van, T. K.; Kang, Y. S. Preparation of $\alpha-\mathrm{Fe}_{2} \mathrm{O}_{3}$ Films by Electrodeposition and Photodeposition of Co-Pi on Them to Enhance Their Photoelectrochemical Properties. RSC Adv. 2015, $5,36307-36314$. 
16. McDonald, K. J.; Choi, K.-S. Synthesis and Photoelectrochemical Properties of $\mathrm{Fe}_{2} \mathrm{O}_{3} / \mathrm{ZnFe}_{2} \mathrm{O}_{4}$ Composite Photoanodes for Use in Solar Water Oxidation. Chem. Mater. 2011, 23, 4863-4869.

17. Zeng, Q.; Bai, J.; Li, J.; Xia, L.; Huang, K.; Li, X.; Zhou, B. A Novel in Situ Preparation Method for Nanostructured $\alpha-\mathrm{Fe}_{2} \mathrm{O}_{3}$ Films from Electrodeposited Fe Films for Efficient Photoelectrocatalytic Water Splitting and the Degradation of Organic Pollutants. J. Mater. Chem. A 2015, 3, 4345-4353.

18. Zhong, D. K.; Cornuz, M.; Sivula, K.; Grätzel, M.; Gamelin, D. R. Photo-Assisted Electrodeposition of Cobalt-phosphate (Co-Pi) Catalyst on Hematite Photoanodes for Solar Water Oxidation. Energy Environ. Sci. 2011, 4, 1759-1764.

19. Barroso, M.; Cowan, A. J.; Pendlebury, S. R.; Grätzel, M.; Klug, D. R.; Durrant, J. R. The Role of Cobalt Phosphate in Enhancing the Photocatalytic Activity of $\alpha-\mathrm{Fe}_{2} \mathrm{O}_{3}$ toward Water Oxidation. $J$. Am. Chem. Soc. 2011, 133, 14868-14871.

20. Pilli, S. K.; Furtak, T. E.; Brown, L. D.; Deutsch, T. G.; Turner, J. A.; Herring, A. M. Cobaltphosphate (Co-Pi) Catalyst Modified Mo-doped $\mathrm{BiVO}_{4}$ Photoelectrodes for Solar Water Oxidation. Energy Environ. Sci. 2011, 4, 5028-5034.

21. Jeon, T. H.; Choi, W.; Park, H. Cobalt-phosphate Complexes Catalyze the Photoelectrochemical Water Oxidation of $\mathrm{BiVO}_{4}$ Electrodes. Phys. Chem. Chem. Phys. 2011, 13, 21392-21401.

22. Wang, D.; Li, R.; Zhu, J.; Shi, J.; Han, J.; Zong, X.; Li, C. Photocatalytic Water Oxidation on BiVO4 with the Electrocatalyst as an Oxidation Cocatalyst: Essential Relations between Electrocatalyst and Photocatalyst. J. Phys. Chem. C 2012, 116, 5082-5089.

23. Abdi, F. F.; Firet, N.; van de Krol, R. Efficient BiVO 4 Thin Film Photoanodes Modified with Cobalt Phosphate Catalyst and W-doping. ChemCatChem 2013, 5, 490-496.

24. Klahr, B.; Gimenez, S.; Fabregat-Santiago, F.; Hamann, T.; Bisquert, J. Water Oxidation at Hematite Photoelectrodes: The Role of Surface States. J. Am. Chem. Soc. 2012, 134, 4294-4302.

25. Seabold, J. A.; Choi, K.-S. Effect of a Cobalt-based Oxygen Evolution Catalyst on the Stability and the Selectivity of Photo-oxidation Reactions of a $\mathrm{WO}_{3}$ Photoanode. Chem. Mater. 2011, 23, 1105-1112.

26. Minero, C.; Maurino, V.; Vione, D., Photocatalytic Mechanisms and Reaction Pathways Drawn from Kinetic and Probe Molecules. In Photocatalysis and Water Purification, Pichat, P., Ed. Wiley-VCH Verlag GmbH \& Co. KGaA: 2013; pp 53-72.

27. Khnayzer, R. S.; Mara, M. W.; Huang, J.; Shelby, M. L.; Chen, L. X.; Castellano, F. N. Structure and Activity of Photochemically Deposited "CoPi" Oxygen Evolving Catalyst on Titania. ACS Catal. 2012, 2, 2150-2160.

28. Tachikawa, T.; Zhang, P.; Bian, Z.; Majima, T. Efficient Charge Separation and Photooxidation on Cobalt Phosphate-loaded $\mathrm{TiO}_{2}$ Mesocrystal Superstructures. J. Mater. Chem. A 2014, 2, 3381-3388.

29. Liu, D.; Jing, L.; Luan, P.; Tang, J.; Fu, H. Enhancement Effects of Cobalt Phosphate Modification on Activity for Photoelectrochemical Water Oxidation of $\mathrm{TiO}_{2}$ and Mechanism Insights. ACS Appl. Mat. Interfaces 2013, 5, 4046-4052.

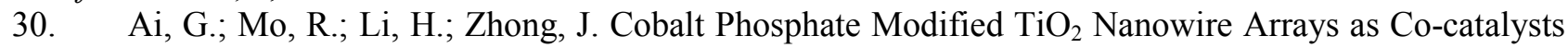
for Solar Water Splitting. Nanoscale 2015, 7, 6722-6728.

31. Spendelow, J. S.; Wieckowski, A. Electrocatalysis of Oxygen Reduction and Small Alcohol Oxidation in Alkaline Media. Phys. Chem. Chem. Phys. 2007, 9, 2654-2675.

32. Das, S. S.; Singh, N. P.; Srivastava, P. K. Ion Conducting Phosphate Glassy Materials. Prog. Cryst. Growth Charact. Mater. 2009, 55, 47-62.

33. Kaspar, T. C.; Droubay, T.; Chambers, S. A.; Bagus, P. S. Spectroscopic Evidence for Ag(III) in Highly Oxidized Silver Films by X-ray Photoelectron Spectroscopy. J. Phys. Chem. C 2010, 114, $21562-$ 21571.

34. McMillan, J. A. Higher Oxidation States of Silver. Chem. Rev. 1962, 62, 65-80.

35. Waterhouse, G. I. N.; Bowmaker, G. A.; Metson, J. B. The Thermal Decomposition of Silver (I, III) Oxide: A Combined XRD, FT-IR and Raman Spectroscopic Study. Phys. Chem. Chem. Phys. 2001, 3, 38383845.

36. Allen, J. P.; Scanlon, D. O.; Watson, G. W. Electronic Structures of Silver Oxides. Phys. Rev. B 2011, 84, 115141.

37. Behrens, P.; Aßmann, S.; Bilow, U.; Linke, C.; Jansen, M. Electronic Structure of Silver Oxides Investigated by AgL XANES Spectroscopy. Z. Anorg. Allg. Chem. 1999, 625, 111-116. 
38. Breyfogle, B. E.; Hung, C. J.; Shumsky, M. G.; Switzer, J. A. Electrodeposition of Silver(II) Oxide Films. J. Electrochem. Soc. 1996, 143, 2741-2746.

39. Zhao, Q.; Yu, Z.; Hao, G.; Yuan, W.; Li, J. Modulated Crystalline Ag-Ci Oxygen-evolving Catalysts for Electrocatalytic Water Oxidation. Int. J. Hydrogen Energy 2014, 39, 1364-1370.

40. Wang, W.; Zhao, Q.; Dong, J.; Li, J. A Novel Silver Oxides Oxygen Evolving Catalyst for Water Splitting. Int. J. Hydrogen Energy 2011, 36, 7374-7380.

41. Joya, K. S.; Ahmad, Z.; Joya, Y. F.; Garcia-Esparza, A. T.; de Groot, H. J. M. Efficient Electrochemical Water Oxidation in Neutral and Near-neutral Systems with a Nanoscale Silver-oxide Catalyst. Nanoscale 2016, 8, 15033-15040.

42. Maurino, V.; Minero, C.; Pelizzetti, E. Preparation of Firmly-anchored Photocatalitically-active Titanium Dioxide Coating Films With Non-gelled Organic-doped Precursors EP1205243 A1, 2002.

43. Zhu, W.; Cui, X.; Liu, X.; Zhang, L.; Huang, J.-Q.; Piao, X.; Zhang, Q. Hydrothermal Evolution, Optical and Electrochemical Properties of Hierarchical Porous Hematite Nanoarchitectures. Nanoscale Res. Lett. 2013, 8, 2.

44. Jing, L.; Wang, M.; Li, X.; Xiao, R.; Zhao, Y.; Zhang, Y.; Yan, Y.-M.; Wu, Q.; Sun, K. Covalently Functionalized $\mathrm{TiO}_{2}$ With Ionic Liquid: A High-Performance Catalyst for Photoelectrochemical Water Oxidation. Appl. Catal., B 2015, 166-167, 270-276.

45. Licht, S.; Naschitz, V.; Halperin, L.; Halperin, N.; Lin, L.; Chen, J.; Ghosh, S.; Liu, B. Analysis of Ferrate(VI) Compounds and Super-iron Fe(VI) Battery Cathodes: FTIR, ICP, Titrimetric, XRD, UV/VIS, and Electrochemical Characterization. J. Power Sources 2001, 101, 167-176.

46. Nellist, M. R.; Laskowski, F. A. L.; Lin, F.; Mills, T. J.; Boettcher, S. W. SemiconductorElectrocatalyst Interfaces: Theory, Experiment, and Applications in Photoelectrochemical Water Splitting. Acc. Chem. Res. 2016, 49, 733-740.

47. Kanan, M. W.; Surendranath, Y.; Nocera, D. G. Cobalt-phosphate Oxygen-evolving Compound. Chem. Soc. Rev. 2009, 38, 109-114.

48. Bediako, D. K.; Costentin, C.; Jones, E. C.; Nocera, D. G.; Savéant, J.-M. Proton-Electron Transport and Transfer in Electrocatalytic Films. Application to a Cobalt-based $\mathrm{O}_{2}$-evolution Catalyst. J. Am. Chem. Soc. 2013, 135, 10492-10502.

49. Puigdomenech, I. Hydra and Medusa software. http://www.kth.se/che/medusa/ (accessed April 11, 2017).

50. Li, X.; Yu, J.; Low, J.; Fang, Y.; Xiao, J.; Chen, X. Engineering Heterogeneous Semiconductors for Solar Water Splitting. J. Mater. Chem. A 2015, 3, 2485-2534.

51. Doyle, R. L.; Lyons, M. E. G. An Electrochemical Impedance Study of the Oxygen Evolution Reaction at Hydrous Iron Oxide in Base. Phys. Chem. Chem. Phys. 2013, 15, 5224-5237.

52. Moon, G.-h.; Kim, W.; Bokare, A. D.; Sung, N.-e.; Choi, W. Solar Production of $\mathrm{H}_{2} \mathrm{O}_{2}$ on Reduced Graphene Oxide- $\mathrm{TiO}_{2}$ Hybrid Photocatalysts Consisting of Earth-abundant Elements Only. Energy Environ. Sci. 2014, 7, 4023-4028.

53. Minero, C.; Mariella, G.; Maurino, V.; Pelizzetti, E. Photocatalytic Transformation of Organic Compounds in the Presence of Inorganic Anions. 1. Hydroxyl-mediated and Direct Electron-transfer Reactions of Phenol on a Titanium Dioxide-fluoride System. Langmuir 2000, 16, 2632-2641.

54. Xu, Y.; Lv, K.; Xiong, Z.; Leng, W.; Du, W.; Liu, D.; Xue, X. Rate Enhancement and Rate Inhibition of Phenol Degradation over Irradiated Anatase and Rutile $\mathrm{TiO}_{2}$ on the Addition of NaF: New Insight into the Mechanism. J. Phys. Chem. C 2007, 111, 19024-19032.

55. Maurino, V.; Minero, C.; Mariella, G.; Pelizzetti, E. Sustained Production of $\mathrm{H}_{2} \mathrm{O}_{2}$ on Irradiated $\mathrm{TiO}_{2}$ - Fluoride Systems. Chem. Commun. 2005, 2627-2629.

56. Sivula, K.; Le Formal, F.; Grätzel, M. Solar Water Splitting: Progress Using Hematite $\left(\alpha-\mathrm{Fe}_{2} \mathrm{O}_{3}\right)$ Photoelectrodes. ChemSusChem 2011, 4, 432-449.

57. Kim, J. Y.; Magesh, G.; Youn, D. H.; Jang, J. W.; Kubota, J.; Domen, K.; Lee, J. S. SingleCrystalline, Wormlike Hematite Photoanodes for Efficient Solar Water Splitting. Sci. Rep. 2013, 3, 2681.

58. Yang, T.-Y.; Kang, H.-Y.; Jin, K.; Park, S.; Lee, J.-H.; Sim, U.; Jeong, H.-Y.; Joo, Y.-C.; Nam, K. T. An Iron Oxide Photoanode with Hierarchical Nanostructure for Efficient Water Oxidation. J. Mater. Chem. A 2014, 2, 2297-2305. 
59. Wang, Z.; Liu, G.; Ding, C.; Chen, Z.; Zhang, F.; Shi, J.; Li, C. Synergetic Effect of Conjugated $\mathrm{Ni}(\mathrm{OH})_{2} / \mathrm{IrO}_{2}$ Cocatalyst on Titanium-doped Hematite Photoanode for Solar Water Splitting. J. Phys. Chem. C 2015, 119, 19607-19612.

60. Jia, L.; Harbauer, K.; Bogdanoff, P.; Herrmann-Geppert, I.; Ramirez, A.; van de Krol, R.; Fiechter, S. $\alpha-\mathrm{Fe}_{2} \mathrm{O}_{3}$ Films for Photoelectrochemical Water Oxidation - Insights of Key Performance Parameters. $J$. Mater. Chem. A 2014, 2, 20196-20202.

61. Zandi, O.; Hamann, T. W. The Potential Versus Current State of Water Splitting with Hematite. Phys. Chem. Chem. Phys. 2015, 17, 22485-22503.

62. Carroll, G. M.; Gamelin, D. R. Kinetic Analysis of Photoelectrochemical Water Oxidation by Mesostructured Co-Pi $/ \alpha-\mathrm{Fe}_{2} \mathrm{O}_{3}$ Photoanodes. J. Mater. Chem. A 2016, 4, 2986-2994.

63. Bora, D. K.; Braun, A.; Erat, S.; Ariffin, A. K.; Löhnert, R.; Sivula, K.; Töpfer, J.; Grätzel, M.; Manzke, R.; Graule, T.; Constable, E. C. Evolution of an Oxygen Near-edge X-ray Absorption Fine Structure Transition in the Upper Hubbard Band in $\alpha-\mathrm{Fe}_{2} \mathrm{O}_{3}$ upon Electrochemical Oxidation. J. Phys. Chem. C 2011, 115, 5619-5625.

64. Braun, A.; Sivula, K.; Bora, D. K.; Zhu, J.; Zhang, L.; Grätzel, M.; Guo, J.; Constable, E. C. Direct Observation of Two Electron Holes in a Hematite Photoanode during Photoelectrochemical Water Splitting. J. Phys. Chem. C 2012, 116, 16870-16875. 
Table of Contents artwork

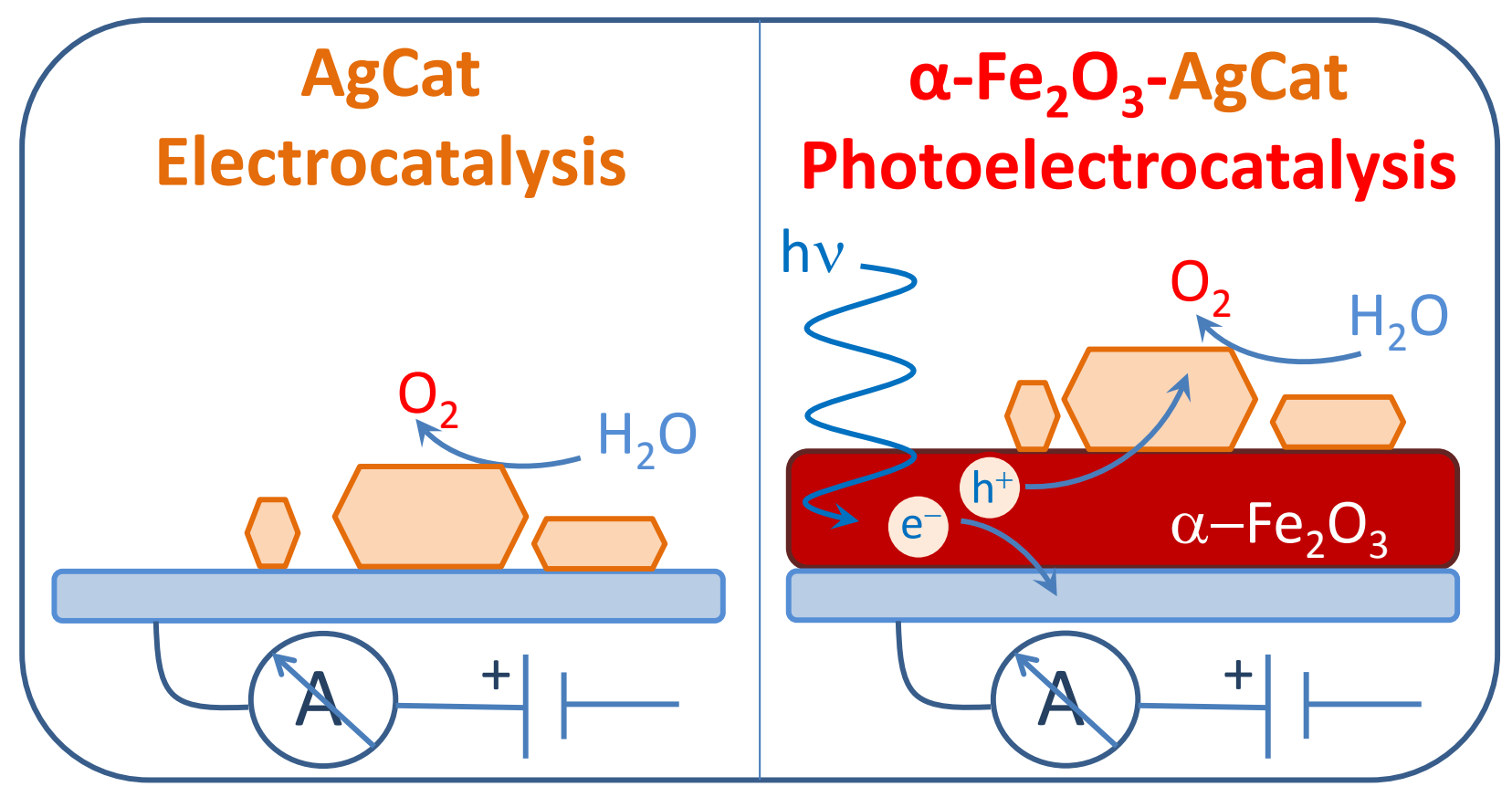

